\title{
A Harmonia tonal de Schoenberg: uma proposta para a análise, realização e composição de lead sheets
}

\author{
Fabiano Araújo (UFES, Vitória, ES) \\ armoniah@gmail.com
}

Fausto Borém (UFMG, Belo Horizonte, MG)

fborem@ufmg.br

\begin{abstract}
Resumo: As metodologias tradicionais do ensino de harmonia no jazz e outras músicas populares geralmente visam fornecer recursos para uma prática de improvisação, cuja abordagem é apenas homofônica. Propomos uma revisão e adaptação da teoria de harmonia tonal de SCHOENBERG $(1999,2004)$ como ferramenta de análise, realização e composição, a partir da lead sheet. Neste artigo de amplo escopo, (1) Conceitos Tonais (Monotonalidade, Movimento das Fundamentais, Notas Substitutas/Substituição, Transformação dos Acordes, Regiões e suas relações), (2) Funções Tonais (Geral, Especifica e de Acordes Vagantes'/de Função Múltipla) e (3) Contextos Tonais (Permutabilidade Maior-Menor, Enriquecimento da Cadência, Tonalidade Expandida, Tonalidade Flutuante, Tonalidade Suspensa) da análise harmônica tonal schoenberguiana são adaptados e explorados utilizando simbologias, teorias e práticas da música popular, e ilustrados com exemplos de duas canções instrumentais do Calendário do Som de Hermeto Pascoal: 9 de agosto de 1996 (PASCOAL, 2000a) e 14 de novembro de 1996 (PASCOAL, 2000b).
\end{abstract}

Palavras-chave: teoria tonal de Arnold Schoenberg; harmonia de Hermeto Pascoal; música popular brasileira, realização de lead sheet.

\section{Schoenberg's tonal harmony: a proposal for analysis, realization and composition of lead sheets}

Abstract: Traditional teaching methodologies of jazz and other popular music usually focus on homophonic improvisation. We propose a revision and adaptation of the tonal harmony theory by SCHOENBERG $(1999,2004)$ to create a basis for analysis, realization and composition of lead sheets. In this comprehensive paper, (1) Tonal Concepts (Monotonality, Root Progressions, Substitution, Transformation of Chords, Regions and their relations), (2) Tonal Functions (Tonal, General and Vagrant Chords/ Multiple Function) and (3) Tonal Contexts (Interchangeability of Major and Minor, Enriched Cadence, Expanded Tonality, Fluctuating Tonality, Suspended Tonality) from the analysis based on schoenberguian tonal harmony are adapted and used through symbols, theories and practices of popular music, illustrated with examples from two songs from Calendário do Som by Hermeto Pascoal: 9 de agosto de 1996 (PASCOAL, 2000a) and 14 de novembro de 1996 (PASCOAL, 2000b).

Keywords: tonal theory of Arnold Schoenberg; harmony of Hermeto Pascoal; Brazilian popular music; lead sheet realization.

\section{1 - Introdução}

Em todo o mundo, boa parte da teoria harmônica da música popular está calcada principalmente na sistematização das relações entre escalas e acordes, largamente difundida nos Estados Unidos na literatura voltada para o jazz, que tem em George RUSSEL (2001/ [1953]), John MEHEGAN (1978/[1959]) e David BAKER (1969) importantes precursores, seguidos por expoentes como DOBBINS (1984), LEVINE (1995) e MILLER (1996,

1997), entre outros. Ao tratar da questão da história da teoria do jazz em seu livro Analyser le Jazz, Laurent CUGNY (2009, p.154-155) aponta as abordagens intuitivas dos primórdios deste discurso teórico que só gradualmente se revestiu de maior rigor metodológico, mas enfatiza que seria um equívoco considerar esta situação como uma fragilidade inicial, pois representa um "sintoma do ambiente necessário para a improvisação". Ao mesmo 
tempo, 0 autor apresenta um panorama sobre as principais "teorias importadas" da música erudita que vêm sendo utilizadas desde a década de 1970 para a análise de solos de jazz: análise schenkeriana, análise semiológica e análise de conjuntos de notas (CUGNY, 2009, p.448-471). Entretanto, até onde nos foi possível rever a literatura, quase não há referências sobre utilização da teoria tonal de Schoenberg. Uma exceção deve ser mencionada, embora não configure, de fato, uma sistematização aplicável à música popular, que é o nosso propósito aqui: em The Harmony of Bill Evans, J. REILLY (1993) utiliza alguns conceitos da teoria tonal schoenberguiana para desenvolver análises sobre a música e improvisação do jazzista que revolucionou o piano no jazz da década de 1960. REILLY $(1993$, p.3) sugere que os livros de Arnold Schoenberg não eram totalmente desconhecidos no seu meio: ". . . se você ler o Harmonia de Arnold Schoenberg, verá onde Bill [Evans] aprendeu esses princípios e, então, poderá seguir minhas explicações com mais clareza".

No Brasil, até o início da década de 1990, a literatura sobre música popular em português praticamente se limitava àquelas publicadas pela editora Lumiar (CHEDIAK, 1986; FARIA, 1991), que refletiam o modelo norte-americano de David Baker. Da mesma forma, traduções de obras teóricas de Schoenberg no Brasil começaram apenas em 1999, com o Harmonia (traduzido por Marden Maluf, Editora Unesp) e, depois em 2004, com Funções Estruturais da Hamonia (traduzido por Eduardo Seincman, Via Lettera, que daqui em diante chamaremos simplificadamente de FEH). Destacamos as contribuições de Norton DUDEQUE (1997), cujo artigo em português trata da questão da função tonal na teoria de Schoenberg e, ainda, DUDEQUE (2005), cujo livro em inglês aprofunda uma sistematização da teoria tonal de Schoenberg, propondo uma revisão de seus escritos, especialmente o manuscrito Gedanke, publicado como "The Musical idea and the logic, technique, the art of its presentation"(SCHOENBERG, 2006).

A teoria de harmonia tonal de Schoenberg fazia parte, como aponta DUDEQUE (2005, p.1), de um projeto teórico (inacabado) que envolve o estudo da forma, da harmonia e do contraponto e foi sistematizada de modo que demonstrasse a evolução do tonalismo em direção às suas fronteiras. Sua teoria da forma (discutida em ARAÚJO e BORÉM, 2013, às p.70-95 desse número de Per Musi) teria suas principais influências a partir do tratado de A. B. Marx (DUDEQUE, 2005, p.15-20) e da teoria do contraponto de Heinrich Bellerman (DUDEQUE, 2005, p.30-31); enquanto que sua teoria da harmonia seria derivada das ideias de Simon Sechter (DUDEQUE, 2005, 20-28) e de Hugo Riemann (DUDEQUE, 2005, p.5867). 0 arcabouço principal da teoria harmônica tonal schoenberguiana se encontra em seus livros Harmonia (do original Harmonielehre, publicado em 1911 em Viena) e FEH (cujo original Structural Functions of Harmony foi escrito em Los Angeles e publicado em Londres em 1954). Em Harmonia, no qual residem os principais ensinamentos, o sistema tonal é abordado através dos processos modulatórios entre as tonalidades do círculo das quintas, processos que caracterizam os Contextos Tonais de 1) Tonalidade expandida; 2) Modulação; 3) Tonalidade Flutuante; 4) Tonalidade Suspensa. Mas em $F E H$, Schoenberg condensa o método de ensinar harmonia apresentado em Harmonia, destacando as progressões do baixo fundamental com harmonias diatônicas, depois com acordes construidos com notas substitutas, com transformações e, finalmente, em harmonias vagantes. FEH também apresenta os Conceitos de Regiões e de Permutabilidade Maior-Menor, absorvendo a Modulação dentro do conceito de Monotonalidade. Assim, ao invés de se medir as distâncias entre tonalidades, uma única tônica é aceita como centro de todo movimento harmônico através de suas várias Regiões. Essa perspectiva permite um dos pressupostos da análise harmônica de modo a perceber os movimentos harmônicos em um nivel mais local (ou micro) - condução de vozes cromática e quase-diatônica - e em nível mais geral (ou macro), de progressões ou sucessões de Regiões. Tal perspectiva nos parece especialmente útil para uma interpretação de lead sheets complexas como as do Calendário do som de Hermeto Pascoal, abordado na parte final do presente artigo e no artigo seguinte a este (p.70-95 desse número de Per Musi).

As relações tonais na teoria schoenberguiana são determinadas por dois princípios básicos: 1) o movimento das fundamentais diatônicas e 2) o princípio das notas comuns. 0 primeiro estabelece que as relações são determinadas qualitativamente por passos de fundamentais diatônicas que promovam efeito discursivo. 0 princípio das notas comuns, por sua vez, identifica quantitativamente as afinidades tonais, isto é, de acordo com o número de notas comuns entre acordes e entre Regiões. Em Harmonia (1999), Schoenberg identifica as notas comuns a dois acordes, como "nexo harmônico". Em FEH(2004), Schoenberg utiliza este mesmo princípio para classificar as relações entre as Regiões:

A Categoria 1 é denominada DIRETA E PRÓXIMA, porque todas estas Regiões possuem cinco (ou seis) notas em comum com a $T$. (...) A Categoria 2 é denominada INDIRETA, MAS PRÓXIMA, porque todas estas Regiões estão fortemente relacionadas às Regiões da Categoria 1 ou à Tônica menor, e possuem três ou quatro notas em comum com a T (SCHOENBERG, 2004, p.91).

$\mathrm{Na}$ análise schoenberguiana, as relações tonais são observadas em três níveis: 1) Relações entre acordes; 2) Relações entre notas diatônicas e não diatônicas; e 3) Relações entre Regiões. A compreensão dessas relações, nesses três níveis, obedece ao princípio da monotonalidade para o qual "qualquer desvio da tônica permanece na tonalidade, não importando se sua relação com ela é: direta, indireta, próxima ou remota" (SCHOENBERG, 2004, p.37).

Buscando uma conexão com o universo do jazz e da música popular, são relevantes os trabalhos de TINÉ (2002), ALMADA (2006) [veja também os artigos desses autores dedicados à música popular, publicados no número 29 de Per Musi] e FREITAS $(1995,2010)$ [veja também outro 
artigo desse autor dedicado à música popular, publicado no número 29 de Per Musi] que revêem, sob o prisma da música popular, as principais referências da teoria tonal desde os seus primórdios até hoje, incluindo Schoenberg. Buscando ampliar e sistematizar esta perspectiva, o presente artigo faz parte de uma pesquisa mais ampla que propõe a adaptação dos elementos teóricos tonais de Schoenberg para uma melhor compreensão e realização da música harmonicamente complexa de Hermeto Pascoal e a simbologia única de suas lead sheets.

De uma maneira geral, as abordagens ou as sistematizações do estudo da harmonia nas correntes da música erudita (especialmente no séc. XIX) estão direcionadas sobretudo para a composição musical escrita. Ao contrário, as correntes de música popular (especialmente o jazz) se direcionam para a improvisação (que poderia ser compreendida como uma composição em tempo real na performance). TINÉ (2002, p.12) acredita que uma das razões desta diferença está na perspectiva de condução de vozes: "... Uma das diferenças reside no fato de o improvisador não ver um acorde como um passo momentâneo do entrecruzamento de vozes, mas como uma cristalização duradoura, que é concebida em função de um modo ou escala que gera tal disposição (TINÉ, 2002, p.12), acrescentando que, em música popular, a condução de vozes é mais priorizada nos estudos de arranjo. FREITAS (1995), reforça essa concepção, afirmando que as relações de combinações entre acordes não se dão pelas conexões resultantes da Condução de Vozes². Assim, o estudo da harmonia voltada para o improvisador prioriza o conhecimento e habilidades com o maior número de escalas e clichês harmônicos para introduzir acordes (com suas funções e tensões específicas) e re-harmonização. Essa prática vem de encontro à afirmação de FREITAS (1995):

No corpus da música popular, a pergunta "Qual acorde pode ser colocado aqui?" é da rotina, é necessária e tem sentido claramente aplicativo. É uma questão que, pode ser respondida com esse caráter eminentemente prático da escolha (FREITAS, 1995, p.1).

Dentro da perspectiva erudita, SALZER (1962, p.51) chama atenção para as restrições de um estudo musical centrado mais na aprendizagem das relações harmônicas e menos na familiaridade com a condução de vozes e 0 contraponto:

0 estudo do contraponto desenvolve sensibilidade para direcionamento do discurso musical, condução das vozes individuais e para criação de acordes através do movimento das vozes. Por outro lado, uma primeira concentração na harmonia, especialmente se baseada no método atual, com seu perpétuo exercicio de cadências e sua indiscriminada categorização de todos acordes como individualizados, pode impedir o ouvido, com a cadência em mente, da capacidade instintiva de perceber movimento e direção (SALZER, 1962, p.51)..

DUDEQUE (2005, p.28-32) lembra que Schoenberg procurou, em suas elaborações teóricas, lançar mão do estudo do contraponto como ferramenta pedagógica de criação, de modo que o estudante utilizasse seu conhecimento quando estivesse compondo.
Nesta direção, propomos que a teoria harmônica schoenberguiana possa prover uma aproximação flexível do contraponto com a harmonia (melódico-harmônicohomofônica) na música popular, facilitando e ampliando a competência não só para a improvisação, mas também para a composição e arranjo.

0 presente artigo constitui a segunda parte de um estudo dos presentes co-autores articulando a música de Hermeto Pascoal e a teoria musical tonal de Arnold Schoenberg. Primeiro, relacionamos a história de vida de Hermeto Pascoal com a formação de suas diversas e ecléticas linguagens harmônicas, tonais e não-tonais (BORÉM e ARAÚJO, 2010). No presente artigo, ainda com este seminal músico brasileiro em vista, buscamos adaptar e aplicar à musica popular os Conceitos Tonais (Monotonalidade, Movimento das Fundamentais, Notas Substitutas/Substituição, Transformação dos Acordes, Regiões e suas relações), as Funções Tonais (Geral, Especifica e Acordes Vagantes/de Função Múltipla) e os Contextos Tonais (Permutabilidade Maior-Menor, Enriquecimento da Cadência, Tonalidade Expandida, Tonalidade Flutuante, Tonalidade Suspensa) do pensamento tonal de Schoenberg (esses termos aparecem em maiúsculas esporadicamente para facilitar a leitura do artigo). No próximo artigo (ARAÚJO e BORÉM, 2013, às p.70-95 desse número de Per Musi), adaptamos e propomos a aplicação dos conceitos de Forma e Variação Progressiva de Schoenberg em duas canções instrumentais do livro de partituras Calendário do som de Hermeto PASCOAL (2000c, 2000d). Finalmente, ilustramos toda a pesquisa apresentando a realização de duas lead sheets de Hermeto PASCOAL (2013) às p.97-98 e às p.100-101 desse número de Per Musi). Ressaltamos que, ao contrário da relação de Bill Evans (músico letrado musicalmente; veja outros artigos e partitura relativos à música de Bill Evans às p.7-14, p.15-20 e p.21-34 nesse volume de Per Musi) com o pensamento de Schoenberg, Hermeto Pascoal (músico autodidata) nunca se orientou pelas ideias ou escritos de Schoenberg.

\section{2 - Conceitos Tonais}

\section{1- Os Conceitos de Monotonalidade e Regiões}

A Monotonalidade se refere ao princípio segundo o qual uma obra tonal tradicional começa e termina na mesma tônica. Leibowitz (citado por DUDEQUE, 2005, p.116), apresenta a monotonalidade como a ideia sob a qual a compreensão das relações tonais implica na inclusão de todos os tons sob o comando de uma única tonalidade. Assim, o conceito de Modulação é substituído pelo Conceito de Regiões, como um movimento (desvio) em direção a outros modos (Regiões), subordinados ao poder central de uma tônica, o que permite uma compreensão de uma obra musical com maior senso de unidade. Uma real mudança de centro tonal será considerada apenas quando uma tonalidade tiver sido abandonada por um tempo considerável e outra tonalidade tenha se estabelecido harmônica e tematicamente de fato.

A possibilidade de inclusão de todos os tons ou notas do sistema no conceito de Monotonalidade deve-se à 
visão do acorde como um composto formado por uma fundamental situada em um grau diatônico, e pelas notas erguidas sobre esta fundamental. Quando são erguidas sobre as fundamentais apenas as notas diatônicas, temos o Campo Harmônico Diatônico. Nos Ex.1, Ex.2 e Ex.3a e $3 b$ mostramos estas estruturas nos Modos Maior e Menor.

A escala menor apresenta-se de três formas: a) Menor Natural: com os graus III, VI e VII abaixados, (Ex.2); b) Menor Harmônica: com os graus III e VI abaixados e 0 VII elevado (Ex.3a); c) Menor Melódica ascendente: com o III grau abaixado e os graus VI e VII elevados (Ex.3b). Os graus abaixados (naturais) são identificados aqui com o símbolo " $b$ ". Os graus elevados são identificados aqui com o símbolo de bequadro: "

A inclusão de notas não diatônicas no sistema é explicada primeiramente no âmbito das notas erguidas sobre as fundamentais, introduzidas através da Transformação dos acordes pelos procedimentos de Substituição, que serão tratados nos tópicos seguintes. Através destes conceitos básicos, Schoenberg relaciona a introdução das notas não diatônicas ascendentes (Ex.4a) com o contexto de Dominantes Secundárias; e das não diatônicas descendentes (Ex.4b), enarmônicas das anteriores, dentro do contexto da Permutabilidade Maior-Menor. Posteriormente, elas são explicadas no contexto da Tonalidade Expandida e Acordes Vagantes.

\section{2- Conceito de Movimento (e Passos) das Fundamentais}

0 principio do Movimento das Fundamentais de Schoenberg, derivado do baixo fundamental de Rameau (via Kimberger e Sechter), determina qualitativamente as relações tonais entre os acordes, em função do efeito discursivo promovido pelos 6 passos diatônicos possíveis na tonalidade: $2^{\mathrm{a}}$ asc/desc, $3^{\mathrm{a}}$ asc/desc, $4^{\mathrm{a}}$ asc e $5^{\mathrm{a}}$ asc.

Essa classificação é feita a partir do equilibrio entre 0 número de notas comuns entre as duas tríades que se sucedem e a comparação entre a posição hierárquica em relação à série harmônica (tônica, quinta e terça) que as notas comuns assumem após o passo. Por exemplo, após um passo de $4^{\text {a }}$ ascendente a partir da tríade do I grau de Dó maior, chega-se à tríade de Fá maior, sobre o IV grau. 0 nexo entre essas duas triades, ou seja, as notas comuns

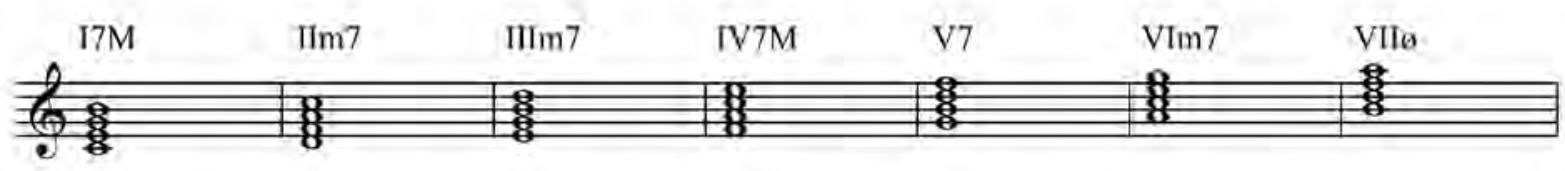

Ex.1 - Campo Harmônico Diatônico do modo de Dó Maior.

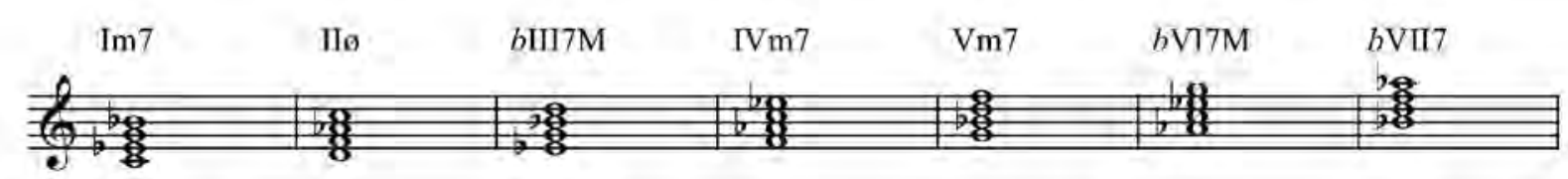

Ex.2- Campo Harmônico Diatônico do modo de Dó Menor Natural.
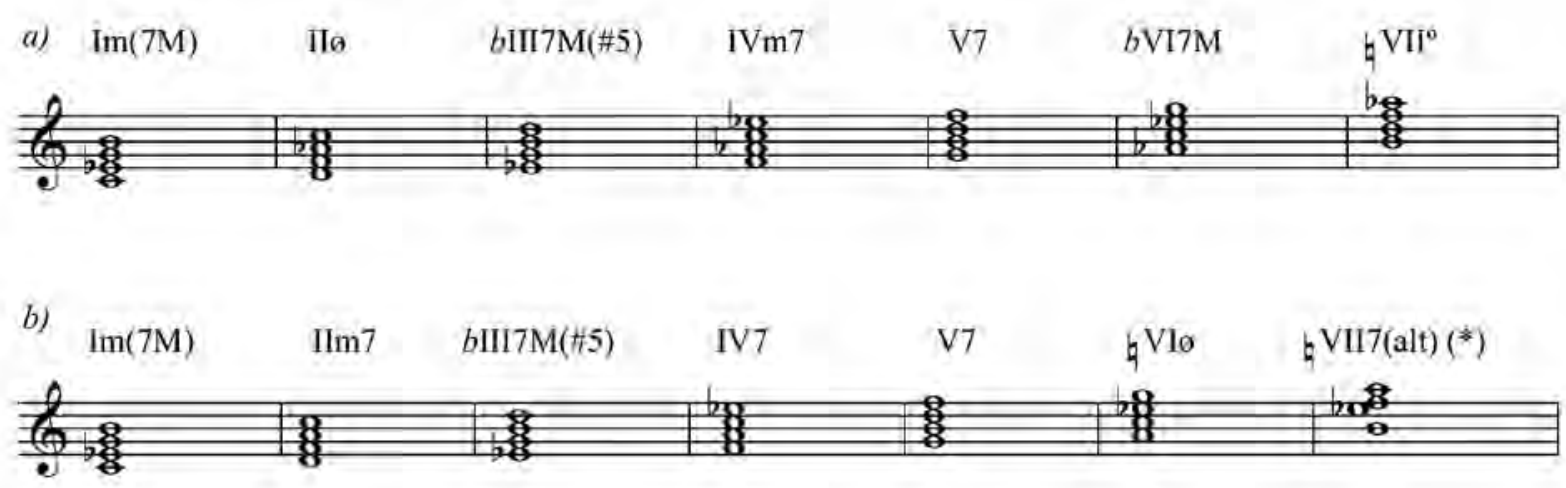

Ex.3a e b - Campo Harmônico Diatônico do modo de Dó Menor com o VI e VII graus elevados. 
entre essas duas tríades, é apenas a nota Dó. Embora exista apenas uma nota em comum, esta nota possui um peso, ou função (qualitativa) de tônica na formação triádica precedente, assumindo na nova tríade (Fá maior) a "melhor" posição possível de acordo com a série harmônica, ou seja,

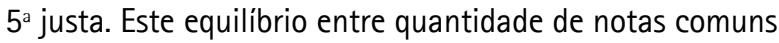
e o peso relativo da função das notas classifica os possiveis passos diatônicos da seguinte forma (Ex.5):

Mais uma vez, o que está em jogo é o quanto o novo passo é capaz de fazer referência à tônica. Os passos crescentes são aqueles que produzem a melhor relação entre quantidade e qualidade, valorizando a função das notas e preservando as notas hierarquicamente mais capazes de referenciar a tônica. Os passos decrescentes, por sua vez, enfraquecem a função das notas. Por exemplo, a $5^{\text {a }}$ do acorde precedente passa a ser $3^{\text {a }}$ no novo acorde. Os passos de $2^{\text {a }}$ asc/desc são considerados fortíssimos porque não produzem notas comuns entre triades, mas porque podem ser vistos como a abreviação de dois passos fortes. Por exemplo, o passo de $2^{\text {a }}$ asc " $\mathrm{C}-\mathrm{Dm}$ ", considerado como "C ${ }^{\left(4^{2} a s c\right)}[\mathrm{F}]^{\left(3^{2} \mathrm{desc}\right)} \mathrm{Dm}$ ".

Schoenberg identifica duas funções produzidas pelos passos de fundamentais : 1) Progressão: que tem a função de estabelecer ou contradizer a tonalidade; e 2) Sucessão: que não tem uma função e não determina uma tonalidade específica (SCHOENBERG, 2004, p.17). A distinção entre uma Sucessão não funcional e uma Progressão funcional é determinada de acordo com os tipos normalizados de progressões das fundamentais. Os movimentos crescentes e fortíssimos caracterizam progressões que se apresentam como modelos cadenciais. Os modelos mais usuais são cadenciais (Ex.6) e de cadência deceptiva (Ex.7):

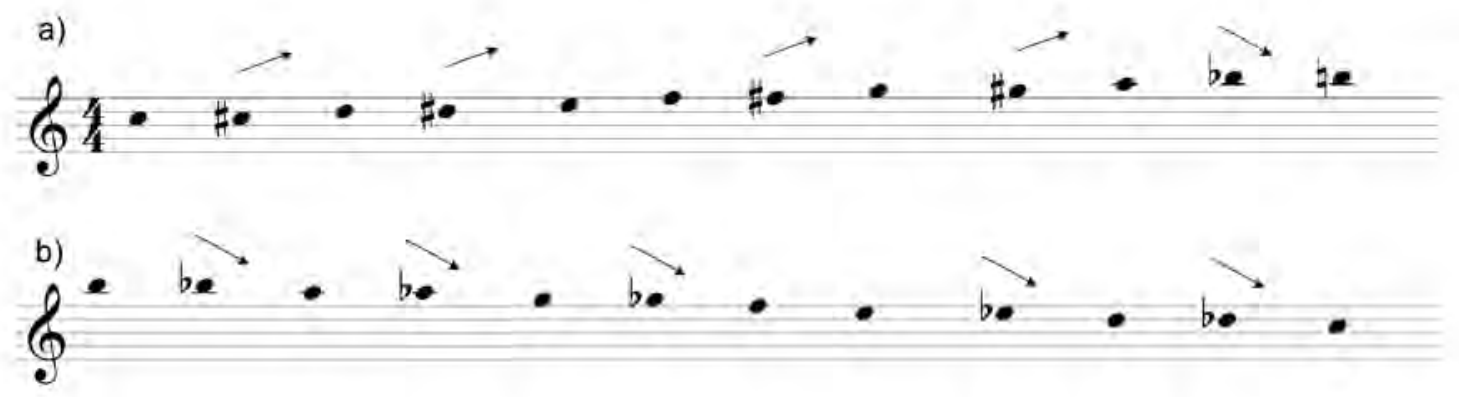

Ex.4a e b - Notas diatônicas e notas substitutas e seus direcionamentos em Dó maior.

\begin{tabular}{|c|c|c|}
\hline Passos & Classificação & Efeito no discurso \\
\hline $4^{\mathrm{a}}$ asc e $3^{\mathrm{a}}$ desc & Crescentes (Fortes) & Ideal, Equilibrado \\
\hline $5^{\mathrm{a}}$ asc e $3^{\mathrm{a}}$ asc & Decrescentes (Fracos) & Redundante, Prolixo \\
\hline $2^{\mathrm{a}}$ asc e desc & Fortissimos & Abreviaçăo de um passo \\
\hline
\end{tabular}

Ex.5 - Classificação dos Passos de Fundamentais e seus efeitos no discurso harmônico.

\begin{tabular}{|c|c|c|c|}
\hline & II - V - I & IV - V - I & VI - V - I \\
\hline Maior & $11 \mathrm{~m} 7-\mathrm{V} 7-\mathrm{I}$ & $\mathrm{IV} 7 \mathrm{M}-\mathrm{V} 7-\mathrm{I}$ & $\mathrm{VIm} 7-\mathrm{V} 7-\mathrm{I}$ \\
\hline Menor & $\mathrm{II}-\mathrm{V} 7-\mathrm{Im}$ & $\mathrm{IVm} 7-\mathrm{V} 7-\mathrm{Im}$ & $\mathrm{bVI7M-V7-Im}$ \\
\hline
\end{tabular}

Ex.6 - Modelos cadenciais

\begin{tabular}{|l|c|c|c|}
\hline & II - V - IV (ou VI, ou III) & IV - V - VI (ou III) & VI - V - IV (ou III) \\
\hline Maior & $\| I m 7-V 7-I V$ (ou VI, ou III) & IV7M - V7 - VI (ou III) & IV7M - V7 - IV (ou III) \\
\hline Menor & $\| \varnothing-V 7-I V m$ (ou bVI ou bIII) & IVm7 - V7 - VI (ou bIII) & IVm7 - V7 - IVm (ou bIII) \\
\hline
\end{tabular}

Ex.7 - Modelos de cadência deceptiva 


\section{3 - Conceito de Notas Substitutas/ Substituição}

Estabelecida a distinção entre a fundamental de um acorde $\mathrm{e}$ as notas erigidas sobre ela, temos que a fundamental de um acorde sempre será diatônica e sua função relacionada ao grau diatônico onde ela está estabelecida. No entanto, as notas erigidas sobre a fundamental podem ser diatônicas e não diatônicas.

As notas não diatônicas são acrescentadas ao sistema devido à "tendência" dos graus secundários do Campo Harmônico Diatônico de solicitarem da tonalidade um mínimo de movimento em torno de si, semelhante ao que ocorre com o I grau, isto é, suas Dominantes secundárias. Este movimento, portanto, permite que a tonalidade tenha uma sensivel para cada grau, fazendo com que estes se comportem como os modos eclesiásticos. Para isso, os graus menores (II - dórico, III - frígio, e VI - eólio) devem imitar o modelo Menor que já havia conquistado o status de Tom (Tonart) por meio da escala menor melódica. Com isso, são adicionados ao sistema os $6^{\circ}$ e $7^{\circ}$ sons elevados no sentido ascendente, e naturais no sentido descendente da escala relativa a cada grau. Por outro lado, os graus maiores (I - jônico, IV - lídio e V - mixolídio) devem imitar o modelo da escala maior. Consequentemente, surgirão as notas não diatônicas preservando seus respectivos sentidos (ascendentes ou descendentes), como mostra o Ex.4a e $4 \mathrm{~b}$ acima. Posteriormente, esta relação com os modos eclesiásticos é levada ao âmbito das Regiões. Devido a esta derivação, Schoenberg usa o termo Stellvertreter para designar as notas não diatônicas. Esse termo significa substituto, representante. Quando uma nota não diatônica surge na tonalidade, ela deve ser vista como uma Substituta, ou seja, representante de um modo eclesiástico/região.

A permissão de movimento em torno dos graus gera consequências sobre a centricidade da Tônica, o que depende do processo de introdução das notas substitutas (Substituição) e pode ocorrer de duas formas, que podem ser vistas como aprimoramentos melódicos da condução de vozes: Cromatismo e Diatonicismo.
Pode-se afirmar que, para Schoenberg, o acorde é um momento vertical de melodias simultâneas, percebidas com um composto de fundamental com outras notas, podendo a fundamental estar omitida. Neste momento, as notas possuem uma função vertical relativa ao acorde (função de $3^{a}$ maior, ou $7^{\text {a }}$ menor, ou $9^{a}$ aumentada etc.) e uma função horizontal relativa à Região em que sua fundamental está ancorada (2^grau, ou 6^grau abaixado, ou 7^وgrau elevado, etc.). Em ambos os casos, a fundamental e as notas devem ser identificadas, caso a caso, como vozes, conduzidas diatônica ou cromaticamente no encadeamento dos acordes segundo os padrões melódicos do contraponto, que ALMADA (2006) denomina de inflexões e classifica como 1) nota de passagem; 2) bordadura; 3) apojatura; 4) escapada; 5) escapada por salto; 5) antecipação; 6) suspensão; 7) cromática; 8) múltiplo cromática e 9) resolução indireta ou cambiata.

Na Introdução Quase-Diatônica das notas substitutas, se produz o efeito de negação da Tônica central. Esse processo é utilizado quando se pretende provocar uma mudança de Região (Modulação), de forma que, em uma voz, não existam pontos cromáticos, mas sim sempre diatônicos à Região pretendida. Em passagens que envolvem Regiões Menores deve-se observar a aplicação das regras das Notas Pivô, ou Neutralização. 0 Processo de Neutralização é um tratamento melódico utilizado para $06^{\wedge}$ e $7^{\wedge}$ graus da escala menor, denominados Pontos Decisivos. Segundo esta regra, existem quatro Pontos Decisivos de trajeto obrigatório, em uma mesma voz (Ex.8, em Lá menor).

No Procedimento Cromático, a função de uma nota substituta aparece como "substituta cromática", atuando principalmente como um Enriquecimento da harmonia, sendo incapaz de produzir uma mudança de Região tonal. 0 procedimento cromático implica na identificação desta nota como cromática, devendo "declarar", na condução de vozes, sua origem diatônica e seu destino, segundo os padrões de Inflexões.

\begin{tabular}{|c|c|}
\hline $\begin{array}{l}1^{\circ} \text { Ponto } \\
\text { Decisivo }\end{array}$ & $\begin{array}{l}\text { Sol\# ( } 7^{\wedge} \text { grau elevado), que deve ir ao Lá, pois somente é usado em razão do passo sensivel. Em } \\
\text { nenhum caso pode seguir-lhe o Sol ou o Fá natural, tampouco o Fá\#. (pelo menos inicialmente). }\end{array}$ \\
\hline $\begin{array}{l}2^{\circ} \text { Ponto } \\
\text { Decisivo }\end{array}$ & $\begin{array}{l}\text { Fä\# (6^ grau elevado), que deve ir ao Sol\#, por somente ter-se introduzido como consequeência } \\
\text { deste. Em nenhum caso pode seguir-lhe o Sol ou o Fá natural, tampouca (pelo menos } \\
\text { inicialmente) o Mi, o Ré, o Lá... }\end{array}$ \\
\hline $\begin{array}{l}3^{\circ} \text { Ponto } \\
\text { Decisivo }\end{array}$ & $\begin{array}{l}\text { Sol ( } 7^{\wedge} \text { grau não elevado), que deve ir ao Fá, pois pertence à escala descendente. Não pode vír } \\
\text { seguido ao Fä\# ou ao Sol\#. O } 7^{\wedge} \text { grau nảo elevado deve ser "resolvido" ou "neutralizado" } \\
\text { descendo ao } 6^{\wedge} \text { grau nāo elevado. }\end{array}$ \\
\hline $\begin{array}{l}4^{\circ} \text { Ponto } \\
\text { Decisivo }\end{array}$ & $\begin{array}{l}\text { Fá ( } 6^{\wedge} \text { grau não elevado), que deve ir ao Mi, pois pertence à escala descendente. O } 6^{\wedge} \text { grau não } \\
\text { elevado deve ser "resolvido" ou "neutralizado" descendo ao } 5^{\wedge} \text { grau da escala. }\end{array}$ \\
\hline
\end{tabular}

Ex.8 - Regra das Notas Pivô para Neutralização (Exemplos em Lá menor). 


\section{4- Conceito de Transformação dos Acordes}

A Transformação é originada através dos procedimentos de substituição. Quando um acorde é transformado, ele recebe uma ou mais notas representantes de uma ou mais Regiões. Nas Transformações, as notas substitutas podem tomar o lugar da $3^{\text {a }}$ e da $5^{\text {a }}$ do acorde, mas não podem tomar o lugar da fundamental.

\begin{abstract}
A transformação não altera a função da fundamental expressa como um grau da escala. Um acorde transformado através da substituição pode mudar, por exemplo, de uma tríade maior para uma menor, diminuta ou aumentada, mas o acorde manterá sua fundamental, isto é, sua função como grau da escala, relacionado a uma Tônica (DUDEQUE,1997, p.6).
\end{abstract}

DUDEQUE (2005, nota de rodapé da p.72) atenta para a distinção, nos escritos de Schoenberg, dos termos "alteração" e "substituição". "0 primeiro [alteração], significa que o mesmo elemento foi modificado[...]",ou seja, implica mudança de alguns aspectos sem a perda da própria identidade; "[...] enquanto o último [substituição] presume que um elemento é usado no lugar de outro".

As Transformações mais simples dos acordes ocorrem no âmbito das notas erguidas sobre a fundamental. Os Exs. $9 a, 9 b$ e 9c demonstram transformações do acorde Dm (Il grau de Dó maior) através da introdução das notas substitutas Fá\# e Láb, gerando os acordes D, Dm(b5), D7, Dø e D7(b5). As notas substitutas representam, respectivamente, a Região da Dominante, e a Região da Subdominante menor (ou da Região da Tônica menor). A substituta Fá\# foi introduzida através da alteração da terça (Fá). No Ex.9b, a substituta Láb foi introduzida através da alteração da quinta (Lá). 0 Ex.9c apresenta as duas substitutas combinadas produzindo um acorde com terça maior e quinta abaixada (b5).

Os casos mais complexos de transformações envolvem as noções de 1) Imutabilidade da Fundamental, em que não é possivel alterar a fundamental; e 2) Omissão da Fundamental, que admite a possibilidade de se omitir a fundamental. Esta concepção reforça a consciência das funções estruturais das progressões das fundamentais e assume que a função estrutural de um acorde depende apenas do grau da escala sobre o qual a fundamental do acorde está ancorada. Qualquer nota que esteja sobre esta fundamental e que constitua uma terça, quinta, sétima, nona etc., "serve somente para dar maior variedade à segunda melodia" (SCHOENBERG, 2004, p.23).

Os casos mais típicos de acordes com fundamental omitida são os acordes de sétima diminuta, e os acordes de sexta aumentada (veja sete casos no Ex. 9 abaixo). 0 Ex.9d mostra o acorde de sétima diminuta "F\#", como um acorde de sétima e nona abaixada sobre o II grau de Dó maior, ou seja, D7(b9) com a fundamental omitida ${ }^{3}$ (Ex.9d). Já o Ex.9e e o Ex.9f mostram o acorde de sexta aumentada (cifrados entre colchetes como Ab7/F\# e Ab7) como o II grau transformado em um acorde de sétima menor e quinta e nona abaixadas e fundamental omitidas. Por outro lado, ocorrerão casos excepcionais, onde a fundamental será relacionada ao grau cromático como é o caso do acorde Napolitano "(b)॥", mostrado no Ex.9g, e outras transformações, que são justificadas via empréstimo de outras Regiões, mostrado no Ex.9g. Schoenberg utiliza o caso do acorde Napolitano para reforçar o princípio da imutabilidade das fundamentais:

0 acorde Napolitano representa uma exceção em relação a alteração das fundamentais. Sua fundamental seria alterada de Ré para Réb em Dó maior acarretando em uma contradição junto ao sistema de fundamentais não alteradas. Isso, entretanto, implicaria em duas fundamentais distintas no segundo grau. Para evitar esse problema, Schoenberg não deriva o acorde de Sexta Napolitana através da transformação, mas sim, como acorde emprestado in toto da Região da Subdominante menor (DUDEQUE, 2005, p.78).

Da mesma forma, vários acordes cujas fundamentais não são diatônicas, podem conviver com a tonalidade nos contextos da Mistura Modal e da Permutabilidade Maior/ Menor. Quando introduzidos nesses contextos, esses acordes não são analisados como transformação da fundamental, mas como inteiramente emprestados de Regiões próximas.

Sobre a notação dos Acordes Transformados, fizemos algumas modificações para promover convergências com as notações da música popular. Os Acordes Transformados através das substitutas são assinalados por Schoenberg com algarismos romanos riscados. Por exemplo, $\mathrm{H}$, significa "Segundo grau transformado". 0 algarismo romano refere-se à fundamental do acorde, seja ela omitida ou não, sendo que as notas substitutas introduzidas não são indicadas na cifragem. DUDEQUE (1997, p.7)

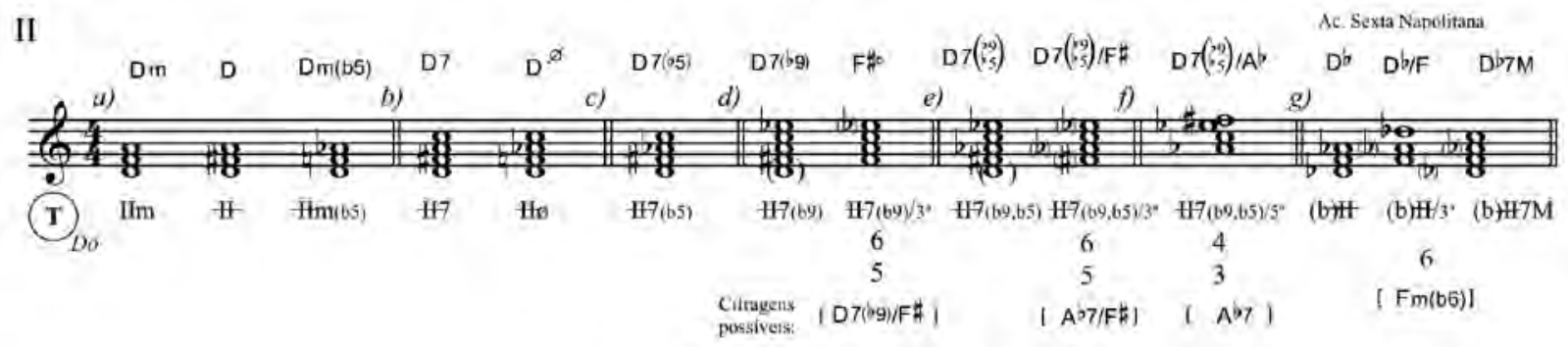

Exs. 9a, b, c, d, e, f, e g - Transformações do Il grau - adaptação do Ex.50 de FEH (Schoenberg, 2004, p.55). 
afirma que a não indicação das notas substitutas é "... justificável uma vez que Schoenberg analisa a harmonia sempre relacionando as fundamentais ao centro tonal" e que as referências às notas substitutas encontramse nos textos das análises. Além disso, Schoenberg se preocupa mais em analisar Regiões Tonais que acordes. A seguir, apresentamos nossa proposta de notação, que justificamos pelo fato de ela evidenciar dados relevantes das práticas da música popular na elaboração de arranjos, na improvisação e na interpretação de lead sheets. Mas essa notação se justifica principalmente em relação à performance, pois evidencia para o intérprete não só os acordes, mas também as Regiões Tonais.

Quando o grau não se apresentar em sua forma original do Campo Harmônico Diatônico, o algarismo romano será riscado (IV) e em seguida será indicada sua estrutura resultante $(\mathbb{V} \varnothing)$. Se esse grau for emprestado de uma Região vizinha - através de Mistura Modal ou Permutabilidade Maior/Menor - e surgir como se tivesse a fundamental alterada, o símbolo (\#) ou (b) ou o bequadro (se for o caso) será colocado entre parênteses antes do grau. Por exemplo, se sobre o IV grau (Fá) de Dó Maior surgir o acorde "F\#ø", este será analisado como (\#)キø para demonstrar a nova configuração do IV grau, sendo que o símbolo "(\#)" antes do grau indica sua situação em relação à Tônica da Região em que se encontra. Portanto, "(\#)林" representa e analisa, ao mesmo tempo, a situação desse grau. 0 Ex.10 (em Dó maior) e o Ex.11 (em Dó menor) ilustram como acordes diatônicos, acordes emprestados e substitutas cromáticas podem ser distinguidos através desta simbologia.

\begin{tabular}{|l|l|}
\hline Símbologia & \multicolumn{1}{|c|}{ Significado } \\
\hline I7M & $\begin{array}{l}\text { indica que o acorde contém a fundamental diatônica sobre o primeiro grau a } \\
\text { não contém nenhuma substituta }\end{array}$ \\
\hline H17 & $\begin{array}{l}\text { indica que o acorde contém a fundamental diatônica sobre o terceiro grau, } \\
\text { porém sua estrutura difere da estrutura do Campo Harmônico Diatônico } \\
\text { maior. Indica que o acorde contém a substitula Sol\# }\end{array}$ \\
\hline HI6 & $\begin{array}{l}\text { indica que o acorde contém a fundamental diatônica sobre o terceiro grau e } \\
\text { a substituta Sib }\end{array}$ \\
\hline II7(b5) & $\begin{array}{l}\text { indica que o acorde contém a fundamental diatônica sobre o terceiro grau a } \\
\text { as substitutas Sol\# e Sib }\end{array}$ \\
\hline (b)H7M & $\begin{array}{l}\text { indica que o acorde contém a fundamental emprestada de outra Regiāo. As } \\
\text { notas Mib e Sib sāo substitutas cromáticas }\end{array}$ \\
\hline
\end{tabular}

Ex.10 - Interpretação da simbologia proposta no

Campo Harmônico Diatônico Maior (exemplo em Dó-maior).

\begin{tabular}{|l|l|}
\hline Símbologia & \multicolumn{1}{|c|}{ Significado } \\
\hline bIII7M & $\begin{array}{l}\text { indica que a acorde contém a fundamental diatônica sobre o terceiro grau do } \\
\text { Campo Harmônico Diatônico menor, e näo contém substituta }\end{array}$ \\
\hline GVlø & $\begin{array}{l}\text { indica que o acorde contém a fundamental diatônica sobre o sexto grau } \\
\text { elevado do Campo Harmônico Diatônico menor, e não contém substituta }\end{array}$ \\
\hline (G) HWø & $\begin{array}{l}\text { indica que o acorde contém a fundamental emprestada de outra Região, e } \\
\text { contém a substituta Mi natural }\end{array}$ \\
\hline (b)H7M & $\begin{array}{l}\text { indica que o acorde contém a fundamental emprestada de outra Região, e } \\
\text { contém a substituta Réb }\end{array}$ \\
\hline blil7(b5) & $\begin{array}{l}\text { indica que a acorde contém a fundamental diatônica sobre o terceiro grau do } \\
\text { Campo Harmônico Diatônico menor, e contém as substitutas Sibb (Lá) e } \\
\text { Réb }\end{array}$ \\
\hline
\end{tabular}

Ex.11- Interpretação da simbologia proposta no

Campo Harmônico Diatônico Menor (exemplo em Dó-menor). 

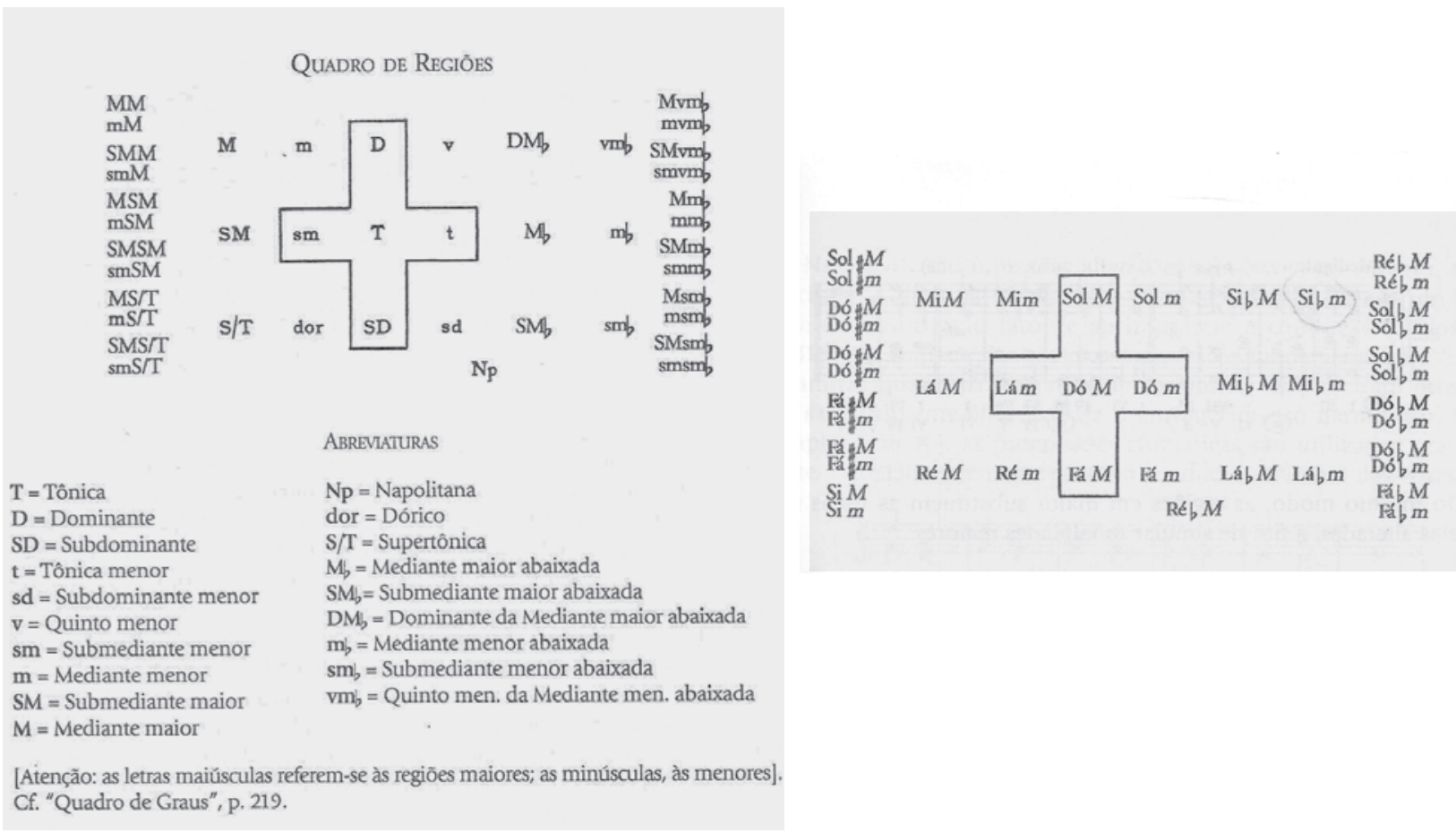

Ex.12a e b - "Quadro de Regiões em Maior" e exemplificação em Dó maior (Extraído de FEH, Schoenberg, 2004, p.38-39).

\section{5 - Conceito de Regiões Tonais e suas relações \\ 2.5.1 - Regiões Tonais}

As Regiões Tonais são segmentos da tonalidade tratados como se fossem tonalidades independentes. Como consequência lógica do princípio da monotonalidade, o conceito de Regiões fornece a compreensão da unidade harmônica de uma música através de suas relações com a Tônica. Em FEH, SCHOENBERG (2004, p.37) esclarece o conceito de Regiões: "(...) segmentos que antigamente seriam considerados como outra tonalidade, são apenas Regiões, um contraste harmônico interno à tonalidade original".

As relações das Regiões com a Tônica diferem de acordo com o modo da Tônica da música, Maior ou Menor. Schoenberg criou o "Quadro de Regiões" (Ex.12a e 12b), onde estas são apresentadas por meio de símbolos que indicam suas respectivas relações com a Tônica. Os símbolos são abreviações que descrevem as funções das Regiões. No Ex.12a, o "Quadro de Regiões em Maior" é apresentado com as abreviações das relações das Regiões com a Tônica. Já o Ex.12b exemplifica as tônicas de um Quadro de Regiões em Dó maior.

DUDEQUE $(2005$, p.102) esclarece a estrutura e disposição lógica do Quadro de Regiões, indicando que as relações com a tônica, mostradas através das abreviações de suas funções, são estruturadas de duas maneiras: (1) Relações verticais, obtidas pelo círculo das quintas; (2) Relações horizontais, com as relações paralelas (homônimas) e as relações relativas. Ele ainda explica que (3) a distância das relações entre as Regiões é determinada pela distância entre as Regiões e a cruz central; e que (4) as Regiões relacionadas e/ou derivadas da Região Subdominante ficam do lado direito, enquanto que as Regiões derivadas da Região da Dominante ficam do lado esquerdo.

As relações das Regiões com a tônica, no modo Menor, são estruturadas conforme o "Quadro de Regiões em Menor" (Ex.13). Deve-se notar que no modo menor, a região $\mathrm{M}$ está uma terça menor acima, assim como a SM está uma terça menor abaixo. As mediantes situadas uma terça maior acima ou abaixo são identificadas, respectivamente, por M\#, e SM\#. Em Menor, o número de Regiões diretamente relacionadas à Tônica é pequeno, pois esta não detém um controle tão direto sobre suas Regiões como no Maior. Isso se deve ao fato de que, devido à sua derivação do modo Eólio ${ }^{4}$, seu estabelecimento enquanto tonalidade se dá via utilização das sete notas da escala diatônica (Jônio). Assim, esses traços característicos do Jônio são gerados, na tonalidade Menor, por meio de alterações dos sexto e sétimo graus. Desta forma, a t (Lá menor) estaria mais suscetivel a promover modulação ou mudar de Região, principalmente para sua relativa maior, a Mediante maior (Dó maior), através da Sub/T (Sol maior). Por outro lado, como observa DUDEQUE $(2005$, p.102-3), as relações da $\mathrm{t}$ com as Regiões cujas modulações são obtidas indiretamente, como a relativa maior M (Dó maior), são ofuscadas, pelo potencial de função de Dominante e polarizador dessas Regiões Intermediárias Maiores. 


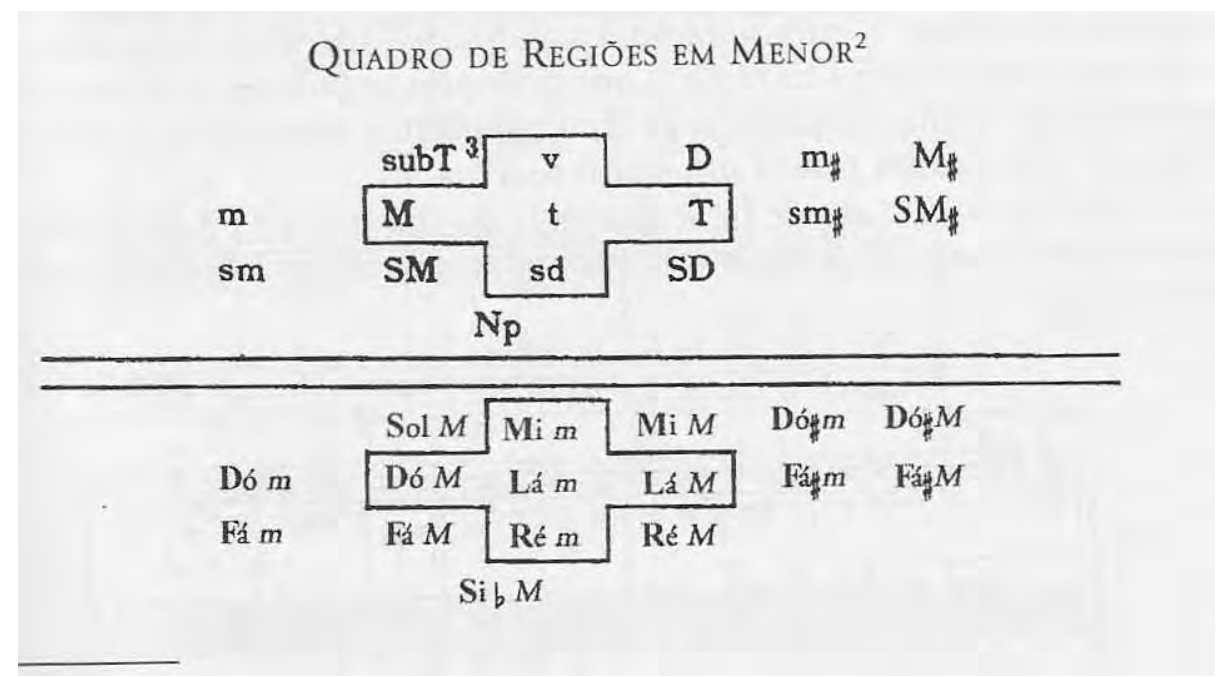

Ex.13 - "Quadro de Regiões em Menor", (Extraído de FEH, Schoenberg, 2004, p.49).

\begin{tabular}{|c|c|}
\hline $\begin{array}{l}\text { Conexāo entre T (Dó maior) e SM (Lá } \\
\text { maior): } \\
\qquad \text { T- }[\mathrm{sm}] \text { - SM }\end{array}$ & $\begin{array}{l}\text { A Regiảo Intermediária [sm] (Lá menor) é relativa } \\
\text { menor da T (Dó maior) e homônima da SM (Lá } \\
\text { maior }\end{array}$ \\
\hline $\begin{array}{l}\text { Conexäo entre T (Dó maior) e SMb } \\
\text { (Láb maior); } \\
\qquad \mathbf{T}-\text { [sd] - SMb. }\end{array}$ & $\begin{array}{l}\text { A Regiảo Intermediária [sd] (Fá menor) relaciona- } \\
\text { se com a T (Dó maior) através da Permutabilidade } \\
\text { entre Maior e Menor, e è relativa menor da SMb } \\
\text { (Láb maior). }\end{array}$ \\
\hline $\begin{array}{l}\text { Conexão entre } \mathbf{T} \text { (Dó maior) e Mb (Mib } \\
\text { maior): } \\
\qquad \mathrm{T}-[\mathbf{t}]-\mathbf{M b} \text {. }\end{array}$ & $\begin{array}{l}\text { A Regiảo Intermediária [t] (Dó menor) é homônima } \\
\text { da T (Dó maior) e relativa menor da Mb (Mib } \\
\text { maior). }\end{array}$ \\
\hline
\end{tabular}

Ex.14 - Progressões com Regiões Intermediárias apoiadas na Permutabilidade Maior/ Menor.

\subsection{2 - Regiões Tonais Intermediárias}

Regiões Tonais Intermediárias podem ser entendidas como Regiões momentâneas, definição encontrada nos Exercícios Preliminares em Contraponto (SCHOENBERG, 2001). Também podem ser compreendidas como Regiões com função de conectar Regiões indiretamente relacionadas. Em FEH (2004), Schoenberg demonstra que a conexão entre a T (Dó maior) e a M (Mi maior), se dá através da Região Intermediária m (Mi menor). As Regiões Intermediárias são utilizadas para promover transições suaves e graduais entre Regiões indiretamente relacionadas ou remotas.

Em Harmonia (SCHOENBERG, 1999), ainda sem utilizar o conceito de Regiões, Schoenberg fala sobre modulação através da intervenção de tonalidades intermediárias. A identificação de uma Região como intermediária dependerá de dois fatores, identificados por DUDEQUE (2005, p.103) como: 1) seu estabelecimento, ou não: 2) sua duração. A principal característica de uma Região Intermediária é seu caráter passageiro e conector. Assim, para uma Região Intermediária, mais vale a utilização funcional de suas características do que seu estabelecimento como Região contrastante dentro da peça.

A Região Intermediária desempenha o papel de criar uma área neutra capaz de proporcionar o giro em direção à Região que se queira alcançar. Por isso, de certa forma, devemos observar o movimento de Regiões sob o mesmo ponto de vista dos movimentos dos acordes. As Regiões Intermediárias fazem parte de um pensamento de prolongamento tonal que surge da ideia de Sucessão e Progressão Harmônica. A primeira

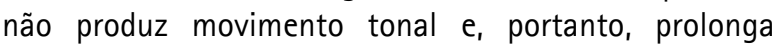
uma tônica ou harmonia qualquer. Já a segunda produz movimento e tem um objetivo tonal. É nesse sentido que 
as Regiões Intermediárias devem ser percebidas, podendo ser uma Região que produz uma Sucessão Harmônica, portanto, prolongando uma Região qualquer, ou podem promover movimento tonal, produzindo uma Progressão Harmônica, se dirigindo para outra Região tonal. A utilização de Regiões Intermediárias apoia-se no conceito de Permutabilidade Maior/Menor (Ex.14).

Conforme dito anteriormente, o movimento entre Regiões pode obedecer ao padrão das Sucessões Harmônicas, produzindo prolongamento de uma Região. 0 Ex.15 ilustra algumas possibilidades:

Em FEH, SCHOENBERG (2004) sugere como algumas Regiões indiretamente relacionadas em Menor podem ser alcançadas por meio de Regiões Intermediárias. Acrescentamos, no Ex.16, uma quarta coluna explicitando as relações aproveitadas para efetuar a conexão entre as Regiões.

DUDEQUE (2005, p.104) estabelece uma distinção entre dois tipos de Regiões: 1) aquelas que definem uma nova área tonal: 2) aquelas que não definem, em qeu as
Regiões Intermediárias não se estabelecem e, portanto, não definem uma nova área tonal, apenas utilizando suas características para promover uma conexão, como uma Progressão, ou uma prolongamento, como uma Sucessão.

\subsection{3 - Classificação das Relações entre Regiões Tonais}

As Regiões são classificadas de acordo com a maneira que se relacionam com a Tônica, analisadas separadamente no modo Maior e no Menor pois, em cada caso, obedecem a critérios diferentes. As classificações aparecem de maneiras diferentes em três fontes primárias (Models for Beginners in Composition, FEH e Exercícios Preliminares em Contraponto).

Em Models for Beguinners in Composition (SCHOENBERG, 1943), as Regiões no Modo Maior aparecem em quatro grupos (Ex.17): (1) Regiões derivadas dos seis modos; (2) Regiões baseadas na relação da Tônica com sua Subdominante menor; (3) Regiões derivadas da Tônica menor; (4) Regiões baseadas na Permutabilidade entre os modos Maior e o Menor.

\begin{tabular}{|l|l|}
\hline $\mathbf{T}$ - [dor] - T : & Prolongamento através de movimento vizinho \\
\hline $\mathbf{T}$ - [sm] - SD & Prolongamento da função tōnica \\
\hline
\end{tabular}

Ex.15 - Prolongamento de Regiões por Sucessões Harmônicas.

\begin{tabular}{|c|c|c|c|}
\hline $\begin{array}{c}\text { Regiāo de } \\
\text { partida }\end{array}$ & $\begin{array}{c}\text { Regiāo } \\
\text { Intermediária }\end{array}$ & $\begin{array}{c}\text { Regiäo } \\
\text { alcançada }\end{array}$ & Relaçöes tonais \\
\hline t (Dó menor) & M (Mib maior) & m (Mib menor) & anti-relativa/homônima \\
\hline $\mathrm{t}$ & SM (Láb maior) & sm (Láb menor) & relativa/homônima \\
\hline $\mathrm{t}$ & $\mathrm{D}$ (Sol maior) & m\# (Mi menor) & dominante/relativa $\left({ }^{\star}\right)$ \\
\hline $\mathrm{t}$ & D (Sol maior) & $\mathrm{M \#}$ (Mi maior) & dominante/relativa da homônima $\left(^{* *}\right)$ \\
\hline$t$ & $T$ (Dó maior) & sm\# (Lá menor) & homônima/relativa \\
\hline$t$ & T (Dó maior) & SM\# (Lá maior) & homônima/homônima da relativa \\
\hline$t$ & SM (Láb maior) & Np (Réb maior) & relativa/subdominante \\
\hline $\mathrm{t}$ & D (Sol maior) & $\operatorname{sm} D$ (Mi menor) & dominante/relativa $\left({ }^{\star}\right)$ \\
\hline$t$ & $D$ (Sol maior) & $\mathrm{SMD}$ (Mi maior) & dominante/relativa da homônima $\left({ }^{* *}\right)$ \\
\hline$t$ & M (Mib maior) & subT (Sib maior) & anti-relativa/dominante \\
\hline$t$ & sd (Fá menor) & SD (Fá maior) & subdominante/homônima \\
\hline
\end{tabular}

Ex.16 - Regiões Intermediárias que podem funcionar para conectar Regiões Indiretamente Relacionadas, segundo indicação em FEH(SCHOENBERG, 2004, p.97). 


\begin{tabular}{|c|c|}
\hline Relação & Regiōes \\
\hline Derivada dos seis modos & dor, S/T, m, Sd, D, sm \\
\hline Baseada na relação da Tônica com a Subdominante menor & Np, Mb, sd, SMb \\
\hline Derivada da Tônica menor & T, v menor \\
\hline Baseada na Permutabilidade Maiorl Menor & M, SM \\
\hline
\end{tabular}

Ex.17 - Classificação das Regiões do modo Maior, como aparece no Models for Beginners in Composition: Syllabus and Glossary (SCHOENBER G, 1943, p.14-15).

\begin{tabular}{|c|c|}
\hline Relaçāo & Regiōes \\
\hline Derivada da Relativa Maior & $\mathbf{M}, \mathbf{S D}, \mathbf{v}$ menor, sd \\
\hline Derivada da Tónica Maior & $\mathbf{T}, \mathbf{m}\left({ }^{*}\right), \mathbf{M}\left(^{*}\right), \mathbf{S D}\left({ }^{*}\right), \mathbf{D}, \mathbf{s m}\left({ }^{\star}\right), \mathbf{S M}\left({ }^{*}\right)$ \\
\hline Derivada da Subdominante menor & $\mathbf{N p}, \mathbf{m}\left({ }^{*}\right), \mathbf{s m}\left({ }^{*}\right)$ \\
\hline Muito Remotas (excluịdas) & dor, $\mathbf{S} / \mathbf{T}$ \\
\hline
\end{tabular}

Ex.18 - Classificação das Regiões do modo Menor, como aparece no Models for Beginners in Composition: Syllabus and Glossary (SCHOENBERG, 1943, p.14-15). OBS: As Regiões assinaladas com ( ${ }^{*}$ ) são mais remotas e utilizadas mais frequentemente na música erudita.

Ainda em Models for Beguinners in Composition (SCHOENBERG, 1943), as relações são classificadas através de três derivações no Modo Menor (Ex.18): (1) Relações derivadas da Relativa maior; (2) Relações derivadas da Tônica maior; e (3) Relações derivadas da Subdominante menor.

Em FEH (SCHOENBERG, 2004), aparece uma classificação segundo o Modo Maior (Ex.19) e o Modo Menor (Ex.20), caracterizando as relações pelas sua proximidade (Próxima, Remota, Distante) e necessidade de intermediação (Direta, Indireta). Schoenberg estabelece cinco categorias: 1) Direta e Próxima; 2) Indireta, mas Próxima; 3) Indireta; 4) Indireta e Remota; 5) Distante.

Norton Dudeque aponta aqui uma aparente inconsistência na classificação da Categoria 4 do modo Maior (Ex.20) em relação ao principio das notas comuns, observando que, ao classificar a Região dor como remota, Schoenberg estaria desconsiderando o princípio das notas comuns, pois esta Região contém cinco notas em comum com a $\mathrm{T}$ em sua forma harmônica, e seis notas em sua forma melódica ascendente ou descendente: "A Região Dórica é classificada como indireta e remota, provavelmente porque esta é considerada em relação à SD, e este fato determina sua relação e distância da Região tônica" (DUDEQUE, 2005, p.112. nota de rodapé).
Finalmente, o Ex.21 mostra as Regiões classificadas como Próximas em Exercícios Preliminares em Contraponto (SCHOENBERG, 2001).

DUDEQUE (2005) busca compatibilizar as três perspectivas do próprio Schoenberg e propõe uma alternativa coerente com as três classificações apresentadas acima:

\begin{abstract}
A classificação das áreas tonais parece atuar de modo que a categoria de relações próximas seja aplicada àquelas Regiões que atuem conforme a sintaxe da $D, S D$, sm e $m$; depois, às Regiões da $\mathrm{Np}, \mathrm{S} / \mathrm{T}$ e dor, que são compreendidas como áreas tonais de aplicação por uso comum. Através da Permutabilidade Maior/ Menor, as Regiões da $t$, sd, v menor, $S M$, e $M$, também são consideradas proximamente relacionadas à Tônica. 0 próximo nivel de relação (Indireta, mas Próxima), aplica-se às Regiões derivadas da Tônica menor, Quinto-menor, e Subdominante menor, e àquelas Regiões que apresentam alterações na fundamental da Região. Finalmente, todas outras Regiões resultam, em relações distantes. (DUDEQUE, 2005, p.112).
\end{abstract}

A inclusão das Regiões $\mathrm{Np}, \mathrm{S} / \mathrm{T}$, e dor na categoria de relações próximas e de aplicação por uso comum, coincide com a classificação apresentada em Models for Beginners in Composition (SCHOENBERG, 1943; Ex.17 e 18 acima). DUDEQUE (2005, p.112) observa ainda que a situação especial da Região Np no Quadro de Regiões em Maior (Ex.12a) denotaria que esta relação ambígua seja derivada da prática comum. Assim, as relações da Dominante e Subdominante, as Relativas, as provenientes da Permutabilidade Maior/ Menor e as da "Prática comum" seriam consideradas de grande afinidade com a Tônica, como mostra o Ex.22. ${ }^{5}$ 


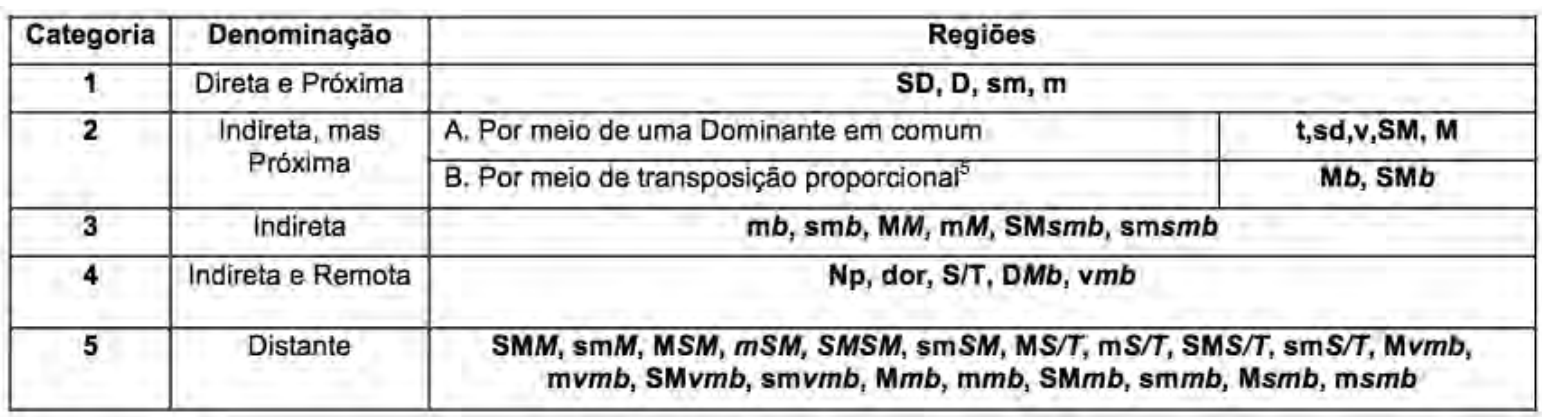

Ex.19 - Classificação das Regiões do modo Maior, como aparece em FEH (SCHOENBERG, 2004, p.91).

\begin{tabular}{|c|c|c|}
\hline Categoria & Denominação & Regiōes \\
\hline 1 & Próxima & $M_{i} T, v$, sd \\
\hline 2 & Indireta, mas Próxima & D, SM \\
\hline 3 & Indireta & $\mathrm{m}, \mathrm{sm}, \mathrm{SD}$ \\
\hline 4 & Indireta e Remota & sm\#, SM\#, m\#, M\#, subT, subt, Np \\
\hline 5 & Distante & Todas as demais Regiôes \\
\hline
\end{tabular}

Ex.20 - Classificação das Regiões no modo Menor, como aparece em FEH (Schoenberg, 2004, p.98).

\begin{tabular}{|c|c|c|c|}
\hline Modo & Categoria & Denominação & Regiōes \\
\hline Maior & 1 & Próxima & SD, D, sm, m, dor \\
\hline Menor & 1 & Próxima & V, sd, subT, M, SM \\
\hline
\end{tabular}

Ex.21 - Classificação das Regiões no modo Maior e Menor, como aparece em Exercício Preliminares em Contraponto (SCHOENBERG, 2001, p.99).

\begin{tabular}{|c|c|c|c|}
\hline Categoria & Denominação & \multicolumn{2}{|l|}{ Regiōes } \\
\hline \multirow[t]{3}{*}{1} & \multirow[t]{3}{*}{ Diretas e Próximas } & A. Por meio de uma Dominante em comum & $\mathrm{D}, \mathrm{SD}, \mathrm{sm}, \mathrm{m}$ \\
\hline & & B. Aplicação por uso comum & Np, S/T, dor \\
\hline & & C. Permutabilidade Maior/Menor & sd, t, v-menor, S $/$, SM, M \\
\hline \multirow[t]{2}{*}{2} & \multirow[t]{2}{*}{ Indiretas mas Próximas } & A. Derivadas da t, sd, v-menor & $\mathrm{Mb}, \mathrm{SMb}, \mathrm{DMb}, \mathrm{Np}$ \\
\hline & & B. Com alteraçāo & $v m b, m b, s m b$ \\
\hline 3 & Distantes & Todas as demais Regiōes & \\
\hline
\end{tabular}

Ex.22 - Classificação das Regiões do modo Maior, como aparece em Music Theory and Analysis in the Writings of Arnold Schoenberg (1874-1951) (DUDEQUE, 2005, p.112). 


\section{3 - Funções Tonais (Geral, Específica e de Acordes Vagantes/Função Múltipla)}

Aqui abordamos o aspecto funcional geral e específico das relações tonais das notas, acordes e Regiões, na produção de progressões ou sucessões. DUDEQUE (1997) identifica dois tipos de funções tonais no pensamento schoenberguiano: (1) a Função Tonal Específica e (2) a Função Tonal Geral. A primeira refere-se às notas e acordes, e a segunda refere-se à utilização das funções específicas das notas e acordes para afirmar ou contradizer uma tonalidade. A estas se junta a Função Tonal dos Acordes Vagantes (ou de Função Múltipla).

Antes de abordar as Funções Tonais, entretanto, sugerimos uma notação que traduza os Princípios da Transformação de Acordes e da Transferência de Função Tonal (discutidos mais abaixo). Como a Transferência de Função Tonal ocorre quase sempre a partir da imitação de modelos cadenciais, propomos aqui o sistema adotado por CHEDIAK (1986), mostrado no Ex.23, cuja notação explicita analiticamente os passos cadenciais.

$\mathrm{Na}$ utilização dessa notação, algumas considerações sobre o modelo cadencial são importantes:

1. cada tom contém uma sensivel tonal - representada pelo sétimo grau da escala - que resolve ou se dirige para o tom;

2. cada tom contém uma sensível modal - representada pelo quarto grau da escala - que resolve ou se dirige para a terça definidora do modo maior ou menor;

3. a sensivel tonal é uma representante em potencial da Região da Dominante;

4. a sensivel modal é uma representante em potencial da Região da Subdominante;

Além dessas características, lembramos a visão de Schoenberg em que, num contexto onde a Tônica seja, por exemplo, Dó maior, uma das funções da nota Si (sensivel tonal) é evitar a possibilidade da nota Sib (definidora da Região da Subdominante, Fá maior) ser percebida como pertencente ao tom, impedindo uma espécie de impulso da percepção rumo a Região da Subdominante.

0 nosso empenho, portanto, deverá concentrar-se em primeiro lugar, em não permitir que se estabeleça o impulso rumo à Subdominante: a sensação de Fá-maior. Melodicamente consegue-se isso com a nota Si natural. 0 Si pertence a três acordes: aqueles dispostos sobre o III, o V e o VII. Dispomos, portanto, desses acordes para expressão harmônica desta intenção (SCHOENBERG, 1999, p.199).

Da mesma forma Schoenberg justifica o uso da nota Fá natural para impedira tendência rumoa Região da Dominante (Sol maior). Com isso, enfatiza-se a função de demarcação dessas notas. Mesmo considerando, pelo desdobramento do mesmo raciocínio citado, o movimento II-V-I como o mais adequado para estabelecer, inequivocamente, a tonalidade, Schoenberg acrescenta: "Não obstante, também outras cadências, mais débeis, podem ser atrativas sob determinadas condições, e por isso discutiremos aqui as aptidões dos outros graus" (SCHOENBERG, 1999, p.204). Ainda assim, Schoenberg caracteriza não só o efeito do III grau como inabitual (e por isso débil), como também exclui o VII pelo desuso. E recomenda, como disponível, apenas o VI grau no lugar do II.

0 direcionamento da sensivel também caracteriza sua função dentro do modelo cadencial. Quando fala sobre notas estranhas ao tom, no capítulo sobre as dominantes secundárias no Harmonia (SCHOENBERG, 1999), e no Capítulo 3 de FEH (SCHOENBERG, 2004), ele caracteriza quatro alterações ascendentes e uma descendente. Observamos que as alterações ascendentes produzem tendências rumo a Regiões do lado do círculo das quintas da Dominante, e a alteração descendente tende a Regiões do lado do círculo das quintas da Subdominante ${ }^{6}$.

Concluindo, propomos a seta contínua para indicar - passo cadencial produzido pela sensivel tonal, preferencialmente onde o movimento de fundamentais seja o de quarta ascendente. Para indicar a cadência deceptiva usaremos a seta contínua cortada. Para indicar o passo cadencial que antecede o movimento da sensivel tonal, e caracteriza a influência da Subdominante, usaremos o colchete. Assim, o conjunto formado pelo colchete e pela seta contínua indica o movimento cadencial geral, mesmo onde não exista a imitação exata do modelo cadencial II - V ou IV - V. Já a representação da função do acorde cifrado se dará por um conjunto de sinais e suas diferentes associações para representar as funções específicas implícitas nas cifras. 0 Ex.24 enumera esses sinais, seus símbolos e seus significados. Os símbolos assinalados com $\left({ }^{*}\right)$ indicam tonalidade expandida, e serão explicados em detalhe no tópico 4.3 .

\begin{tabular}{|c|c|}
\hline$v_{7}$ & $\begin{array}{l}\text { A seta curva contínua indica resoluçảo com movimento de quarta } \\
\text { ascendente ou resoluçăo de uma Dominante disfarçada. }\end{array}$ \\
\hline $\lim \quad v 7$ & $\begin{array}{l}\text { O colchete contínuo indica o vinculo ligando o lim (funçăo } \\
\text { Subdominante) ao V7 (função Dominante) por movimento de quarta } \\
\text { ascendente }\end{array}$ \\
\hline
\end{tabular}

Ex.23 - Notação com sinais analíticos cadenciais em passos de $4^{\mathrm{a}}$ ascendente (CHEDIAK, 1986). 
Em relação aos Princípios da Transformação de Acordes e da Transferência de Função Tonal, as relações tonais e funcionais, dentro do pensamento schoenberguiano, são influenciadas por dois fenômenos harmônicos: (a) Transformação de Acordes, que "... não admite substituição da fundamental e é baseada nas sete funções fixas dos sete graus da escala" (DUDEQUE, 1997, p.9); e (b) Transferência de Função, que "... sugere uma função móvel..." (DUDEQUE, 1997, p.9). Por exemplo, um acorde pode surgir sobre um determinado grau da escala de uma Região, ser transformado e seguir sua tendência rumo a outras Regiões. Mesmo que a configuração do acorde contenha notas transformadas, a função específica da sua fundamental permanece inalterada, indicando sua relação com a tônica. Por outro lado, ao seguir suas tendências rumo a outra Região, sua fundamental adquire nova função e deve ser analisada na Região à qual está naquele momento.

A Transformação de Acordes, produzida pelo processo da Substituição, acarreta uma nova configuração de um dado acorde sobre um grau diatônico. Depois de assumir sua nova configuração, esse acorde tende a imitar os modelos convencionais de movimento de fundamentais. Essa tendência pressupõe a transferência da função de outro grau escalar ao grau transformado. No Ex.25, o acorde sobre o I grau foi transformado através da

\begin{tabular}{|c|c|c|}
\hline Sinais & Símbolo & Significado \\
\hline Algarismo romano & 17M & Grau diatônico, indicando a funçâo da fundamental do acorde sobre ele. \\
\hline $\begin{array}{l}\text { Algarismo romano } \\
\text { cortado }\end{array}$ & H & Grau diatônico transformado, com a nota substituta sobre a fundamental do acorde. \\
\hline \multirow[t]{2}{*}{$\begin{array}{l}\text { Configuração do } \\
\text { grau }\end{array}$} & Ilø & $\begin{array}{l}\text { Acorde com o grau especificado e sua contiguraçẫo (a grau nāo cortado indica uma } \\
\text { configuraçâa diatônica). }\end{array}$ \\
\hline & II 7 & $\begin{array}{l}\text { Acorde com o grau especificado e sua configuração (o grau cortado indica uma } \\
\text { configuraçấo não diatônica, a partir da qual pode-se deduzir a nota substituta). }\end{array}$ \\
\hline $\begin{array}{l}b \text { ou \# } \\
\text { entre parênteses }\end{array}$ & (b)H7M & $\begin{array}{l}\text { Acorde inteiramente emprestado de outra Regiâo, provavelmente por } \\
\text { Permutabilidade Maior/Menor. }\end{array}$ \\
\hline Seta contínua & & Acorde com sensivel ascendente cadencial (com resolução para o alvo indicado). \\
\hline $\begin{array}{l}\text { Seta contínua } \\
\text { cortada }\end{array}$ & & Acorde com sensivel ascendente cadencial (sem resoluçâo para o alvo indicado) \\
\hline Colchete & & Acordes com tendências de Subdominante cadencial. \\
\hline $\begin{array}{l}\text { * Colchete } \\
\text { tracejado }\end{array}$ & L...- & $\begin{array}{l}\text { Acordes com tendências de Subdominante cadencial com recurso da Tonalidade } \\
\text { Expandida. }\end{array}$ \\
\hline $\begin{array}{l}\text { * Colchete } \\
\text { tracejado }+(\mathrm{Np})\end{array}$ & $\begin{array}{l}(\mathrm{Np}) \\
\mathrm{L}-\ldots-1\end{array}$ & Acordes com funçâo de cadência Napolitana (normalmente com a \#11). \\
\hline $\begin{array}{l}\text { Abreviação da } \\
\text { Regiāo }\end{array}$ & $\mathbf{T}$ & Função da Regiāo (conforme o Quadro de Regiōes) \\
\hline
\end{tabular}

Ex.24 - Adaptação e explicação da notação analítica de análise harmônica.

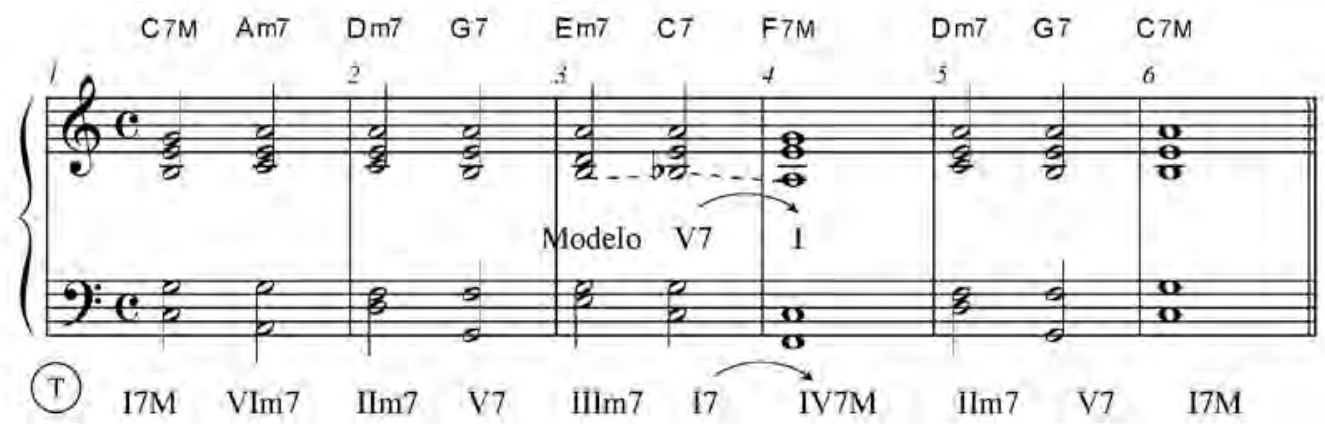

Ex.25 - Transformação de Acorde e Transferência de Função com o modelo V7 - I . 
introdução cromática da substituta Sib (segundo tempo do c.3). Essa nova configuração (acorde de sétima da Dominante) tende ao movimento típico da função do V7 grau diatônico, função Dominante, função que foi transferida para o I grau transformado.

No Ex.26, o V7 grau foi transformado através da introdução cromática da substituta Sib (segundo tempo do c.3), adquirindo a configuração Gm7. Essa nova configuração tende a imitar os modelos IIm7 - V7, ou IVm - V7. Nesse caso, o acorde Gm7 imitou a função de IIm grau cadencial, em direção ao I grau transformado em 17. Houve a transferência da Função do IIm e V7 graus para os graus Vm7 e 17 transformados.

Outras possibilidades poderiam surgir a partir desse mesmo acorde menor. 0 Ex.27 demonstra a imitação do modelo IVm - V - I, fazendo com que o Gm7 siga para o A7 (primeiro e segundo tempos do c.3), preparando - Dm. Segundo Schoenberg, "transformações que alteram a quinta justa em diminuta tendem a ser seguidas por uma tríade maior, de acordo com o padrão II V em menor" (SCHOENBERG, 2004, p.62). No c.6 do Ex.27 mostramos essa tendência, com o III grau transformado. 0 procedimento de imitação dos modelos e, consequentemente, da transferência de função, é responsável por um grande enriquecimento das relações dentro do sistema tonal.

\section{1 - Função Tonal Geral}

A conceituação de Função Tonal Geral está diretamente ligada à expressão da relação dos elementos específicos a uma determinada tonalidade. Assim, os elementos sempre estarão atuando no sentido de afirmar ou estabelecer uma tonalidade - função centrípeta -, ou, no sentido de contradizer uma tonalidade - função centrífuga. Uma tríade tem, em potencial, uma tendência centrífuga, e por isso, necessita da cadência (função centripeta), para anular esse efeito, e proporcionar a centricidade. DUDEQUE (1997) ressalta a importância da função tonal na teoria schoenberguiana quando relacionada ao principio da monotonalidade:

Este conceito é muito mais amplo e complexo do que normalmente os teóricos afirmam e parte do princípio de que uma obra tonal tem suas funções tonais especificas e gerais relacionadas a uma tonalidade única que domina a obra por inteiro, representada pelo principio da monotonalidade (DUDEQUE, 1997, p.3).

Patricia Carpenter e Severine Neef (SCHOENBERG, 2006), citados por DUDEQUE (1997), sugerem que, da mesma

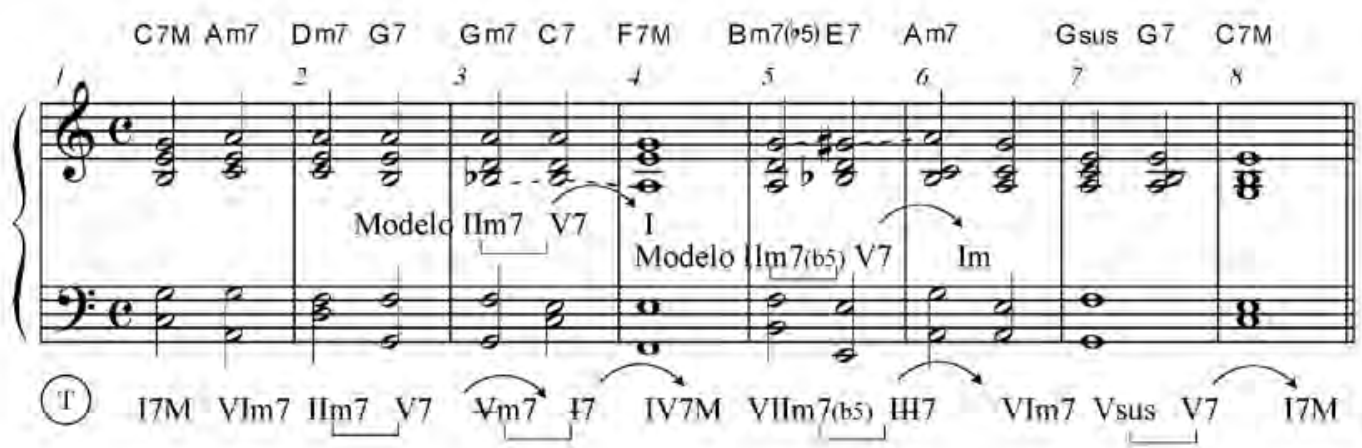

Ex.26 - Transformação de Acorde e Transferência de função com o modelo IIm7 - V7 - I.

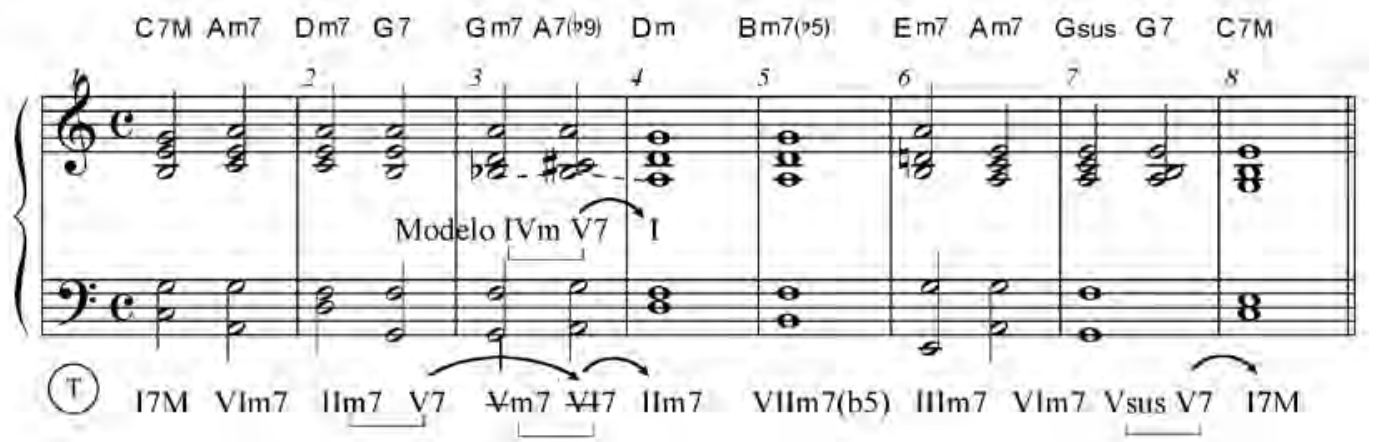

Ex.27 - Transformação de Acorde e Transferência de função com o modelo $I V m 7$ - V7 - I. 
forma como a conceito de monotonalidade engloba todas as tonalidades em um sistema inclusivo, este "envolve uma rede de funções definidas pelos graus da escala, em que todas as notas, acordes e Regiões tonais, cada qual com sua função específica, são relacionados a uma tônica central".

Recordando que, para Schoenberg, o acorde deve ser compreendido a partir de dois elementos - sua fundamental e as notas erigidas sobre essa fundamental - estes elementos específicos assumem funções gerais independentemente um do outro. A fundamental, através da Transferência de Função assume função centrífuga, de negação à tônica central, pois faz referência a outras tônicas. Por outro lado, as notas erigidas sobre o grau, quando percebidas como transformadas, isto é, produto da substituição e com um novo direcionamento, possuem relação com a tônica central. É nesse sentido que DUDEQUE (1997, p.9) afirma que os princípios da Transformação de Acorde e da Transferência de Função devem ser interpretados como funções gerais complementares.

\section{2 - Função Tonal Específica}

A Função Tonal Específica das notas consiste em relacionar as notas aos graus de uma escala relacionada à tônica de uma tonalidade ou Região tonal. Por exemplo: A nota (Sol\#), em Dó maior, poderia assumir a função específica de VII grau (sensível) da Região da sm (Lá menor). Outro exemplo: A nota (Fá\#), em Dó maior, poderia assumir a função de VI grau da Região sm (Lá menor) ou, em outro contexto, a função de VII grau (sensivel) da Região D (Sol maior). Já a Função Tonal Específica dos acordes é expressa pela relação de sua fundamental com um determinado centro tonal, ou Região. Da mesma forma, um determinado segmento de uma Região é relacionado a um centro tonal como se fosse um grau de uma escala, incluindo a função dos acordes e notas.
Uma nota individual possui a capacidade de expressar uma tonalidade se assumir a função de determinados graus característicos, que são responsáveis por estabelecer e diferenciar as tonalidades: o $4^{\wedge}$ e $07^{\wedge}$ graus no Modo Maior; e o $6^{\wedge}$ e o $7^{\wedge}$ graus elevados no Modo Menor (Ex.28).

Essas notas possuem sua Função Específica independentemente do acorde ao qual estão ligadas, função que está diretamente relacionada aos processos de substituição cromática e quase-diatônica (especialmente quando executada pelo processo da Neutralização). A neutralização ou sua falta determina a função de uma nota como substituta cromática (centripeta), ou substituta quase-diatônica (centrifuga).

$\mathrm{Na}$ teoria schoenberguiana, a Função Tonal Específica de um acorde é dada por sua fundamental, que define sua relação com um centro tonal. As fundamentais estão fixadas sobre os graus da escala de referência - Maior ou Menor - e são identificadas com os nomes tradicionais das funções tonais (Ex.29).

0 lugar que a fundamental do acorde ocupa, dentro da escala, determina sua relação funcional com a tônica. Esta relação independe da configuração do acorde. Por outro lado, deve-se estar atento a outros fatores que determinam o estabelecimento de uma função em um acorde: (a) seu Contexto Tonal; e (b) a noção de Região. 0 Contexto Tonal está ligado à relação do acorde com os acordes que o antecedem ou que o sucedem. Esta relação pode promover uma Sucessão ou uma Progressão e, com isso, determinar o significado harmônico desse acorde. Já a Região implica no conhecimento do campo harmônico e das notas características das Regiões, que podem estar atuando em contexto, quer no sentido de se estabelecerem

\begin{tabular}{|c|c|c|}
\hline Modo Maior & 4 & 7 \\
\hline Modo Menor & $6^{\wedge}$ & $7^{\wedge}$ \\
\hline
\end{tabular}

Ex.28 - Graus característicos nos modos Maior e Menor.

\begin{tabular}{|c|c|c|}
\hline Função & Modo Maior & Modo Menor \\
\hline tônica & I & I \\
\hline supertônica & II & II \\
\hline mediante & III & bIII \\
\hline subdominante & IV & IV \\
\hline dominante & V & V \\
\hline submediante & VI & bVI \\
\hline subtônica & - & bVII \\
\hline
\end{tabular}

Ex.29 - Funções Tonais das Fundamentais dos acordes nos modos maior e menor. 
(como contraste), quer no sentido de passagem (como Regiões Intermediárias), conectando ou prolongando Regiões. Finalmente, a determinação da Função Especifica de um acorde deve observar os principios da Transformação de Acordes e da Transferência de Função.

\section{3 - Função de Acordes Vagantes (ou de Função Múltipla)}

Os Acordes Vagantes formam uma categoria especial de acordes que podem assumir a função de vagar ou transitar livremente sobre diferentes Regiões harmônicas, graças à flexibilidade de transformação dos graus. Segundo Schoenberg, tais acordes:

Não pertencem exclusivamente a nenhuma tonalidade, senão que, sem alterar sua configuração (nem sequer é necessária a inversão bastando uma relação imaginária com a fundamental), podem pertencer a muitas tonalidades, muitas vezes a quase todas" (SCHOENBERG, 1999,p.286).

Estes acordes são derivados das Transformações e podem ter funções múltiplas devido às suas constituições especificas. Os casos mais evidentes são os acordes de sétima diminuta, a tríade aumentada e o acorde de sexta aumentada e suas inversões.

$\mathrm{Na}$ teoria da música popular, os acordes vagantes correspondem aos acordes de Substituição de Dominantes. Por exemplo, o II7 grau de Dó maior (D7) pode ser transformado com a alteração da quinta e da nona, assumindo uma configuração semelhante a Ab7. $\mathrm{Na}$ música popular, dizemos que esses acordes são substitutos, ou, Ab7 é o subV7 (Dominante substituta) de D7. Outra maneira de observar essa relação seria reconhecer a presença do mesmo trítono na estrutura desses acordes. Acordes Dominantes que possuem o mesmo trítono são substitutos entre si, ou seja, são Acordes Vagantes correspondentes. As correspondências entre os acordes vagantes são demonstradas no tópico seguinte, dos Contextos Tonais.

\section{4 - Contextos Tonais}

Finalmente, na análise schoenberguiana, podemos reconhecer as relações tonais em Contextos Tonais por meio (1) Enriquecimento da Cadência, (2) Permutabilidade entre Maior e Menor e Mistura Modal, (3) Tonalidade Expandida, (4) Tonalidade Flutuante e (5) Tonalidade Suspensa. A identificação dos contextos tonais está diretamente ligada à percepção do direcionamento do movimento do discurso harmônico. Esse direcionamento é observado a partir da leitura dos elementos estruturais e de Prolongamento ${ }^{7}$ nos três níveis da análise: (1) Regiões, (2) fundamentais dos acordes, (3) notas dos acordes.

\section{1- Contexto de Permutabilidade Maior-Menor}

$\mathrm{Na}$ tendência de enriquecimento da tonalidade, Schoenberg destaca a Permutabilidade entre Maior e Menor, procedimento também identificado como Mistura Modal (Mode Mixture). Em Harmonia (SCHOENBERG, 1999), este procedimento é apresentado no capítulo "Relações com a Subdominante menor", com a introdução de acordes desta Região ao Campo Harmônico Diatônico. Em FEH (SCHOENBERG, 2004), o procedimento é apresentado de forma mais sistemática com a introdução de acordes de Regiões consideradas próximas à Tônica, como a t (Tônica menor), o v menor (Quinto menor), além da sd (Subdominante menor). Na maioria das vezes os acordes derivados dessas relações (Ex.30) são obtidos por transformação das notas sobre a fundamental, porém, em alguns casos, Schoenberg parece admitir a alteração da fundamental. A esse respeito DUDEQUE (2005) afirma:

\footnotetext{
No exemplo que ilustra os acordes substitutos, Schoenberg endereça todos os acordes em relação à tônica maior. Obviamente ele considerou, nessa ilustração específica, a possibilidade de alteração da fundamental, e consequentemente a escala cromática como referencial. Entretanto, essa não é a prática adotada em FEH. Schoenberg analisa um vasto repertório de excertos da literatura musical de acordo com o sistema de fundamentais diatônicas. (DUDEQUE, 2005, p.79)
}

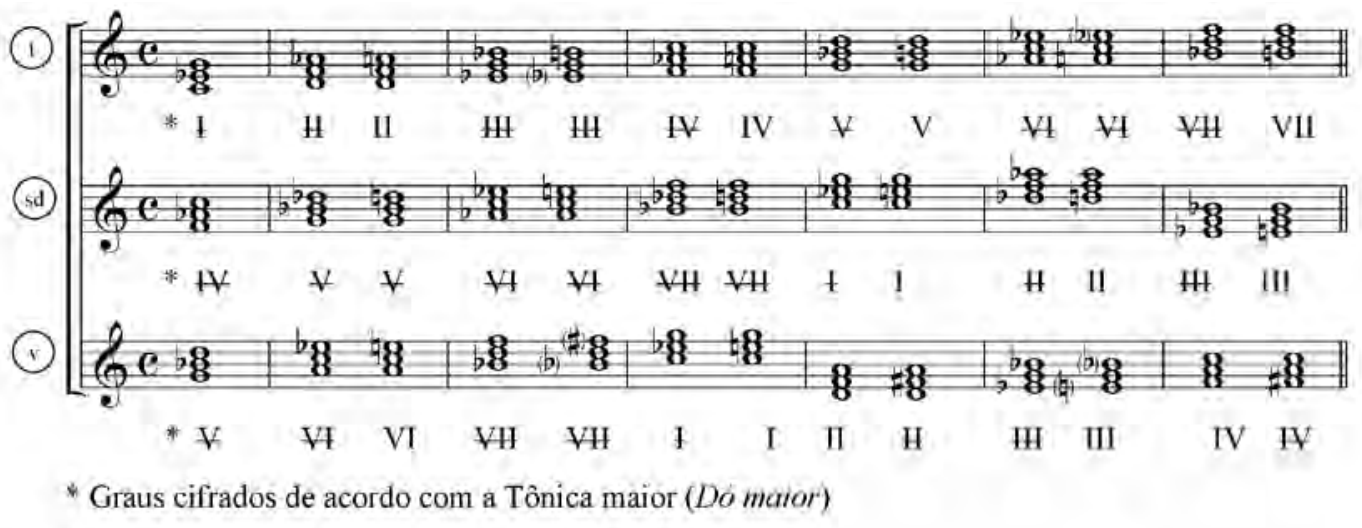

Ex.30 - Acordes emprestados por Permutabilidade entre Maior e Menor

(Extraido de FEH, SCHOENBERG, 2004, p.73) ${ }^{8}$. 
Assim, esses acordes são percebidos como emprestados das Regiões próximas, com as substitutas introduzidas cromaticamente, assumindo, desta forma a característica de notas guias. A substituição cromática desempenha importante papel nesse contexto de Mistura Modal.

A Permutabilidade entre Maior e Menor traz a possibilidade do acorde Napolitano, emprestado do sexto grau da Região da Subdominante menor, acorde que passou a ser utilizado como clichê harmônico. Em Dó maior temos Db7M. Na discussão sobre a compreensão desse acorde no contexto tonal, SCHOENBERG (1999, p.338) afirma que "Seu aparecimento típico é como imitação do II grau da cadência. Por isso têm-se admitido que ele seja uma nova transformação cromática do II grau". Mas, logo em seguida, Schoenberg levanta a hipótese de que seja possivel a existência de duas fundamentais sobre o segundo grau da escala, assim como acontece com o sexto e sétimo graus da escala menor, projetando "uma espécie de princípio fundamental à consideração dos eventos harmônicos: a escala cromática" (SCHOENBERG, 1999, p.338).

Assim, Schoenberg considera o acorde de Sexta Napolitana como representante do segundo grau na cadência, de onde vem seu uso típico. Embora possa ser alcançado por transformação, não é considerado como derivado do processo de transformação, mas sim como acorde totalmemte emprestado da Região da Subdominante menor. Ao uso típíco do acorde napolitano denominamos Cadência Napolitana, que segue dois modelos: (b)H7M V7 - I e (b)H7M - I. É possível, portanto, a imitação dos modelos da cadência Napolitana, descendo por semitom em direção aos graus diatônicos.

Se a tonalidade de referência estiver no modo Menor, a Permutabilidade dá-se da seguinte forma:

\begin{abstract}
Partindo do modo menor, recomendo a princípio, aproveitar meramente a relação obtida através da tonalidade maior homônima. Assim por exemplo em Dó-menor, seriam os acordes relacionados à Subdominante menor de Dó-maior. Mais tarde, 0 aluno poderá também aproveitar o alargamento dessa relação (através da tonalidade maior paralela, isto é: em Dó-menor, a de Mib-maior) (SCHOENBERG, 1999, p.335).
\end{abstract}

Em um exemplo em Dó menor (Ex.31), mostramos como seria este alargamento de relações para as 3 regiões próximas (t, sd, v-menor) tanto da maior homônima (Dó maior) e da maior relativa.

\section{2- Contexto de Enriquecimento da Cadência}

A expressão da tonalidade ocorre em dois níveis: (1) Nivel das Fundamentais: que é representado pela função dos graus, e por isso, mantém-se essencialmente diatônico; (2) Nível da Substituição: que ocorre sobre as notas erigidas sobre a fundamental (mesmo que esta esteja omitida). Reforçando a importância das fundamentais diatônicas, Schoenberg afirma: "A alteração das notas naturais em notas estranhas, geralmente, não mudará a qualidade funcional do grau sobre o qual o acorde está erigido" (SCHOENBERG, 1942, glossário p.13).

Desta forma, percebemos que, na expressão da tonalidade, ocorre o convívio de um elemento definidor das relações tonais (as fundamentais diatônicas), e de um elemento que funciona como ampliador e enriquecedor dessas relações (a substituição).

Leonard Stein, citado por DUDEQUE (2005, p.78-79), identifica três formas de extensão das relações, através da substituição:

1. Enriquecimento das progressões através de sensiveis ascendentes ou descendentes:

2. Enriquecimento dos recursos da cadência com o prolongamento da função da fundamental, e com as possibilidades da Permutabilidade Maior/Menor;

3. Produção de Regiões conduzidas como uma tonalidade.

As duas primeiras possibilidades podem ser identificadas como Cadência Enriquecida, pois implicam na ocorrência da substituição cromática, enquanto a última depende da substituição quase-diatônica, através do processo de Neutralização. Portanto, a identificação da Cadência Enriquecida depende da produção de progressões no movimento das fundamentais; e dos procedimentos cromáticos no nível da substituição. Porém, há ainda a possibilidade de, no nível das fundamentais, identificar "elaborações da função das fundamentais principalmente sob a forma de prolongamento da fundamental" (DUDEQUE, 2005, p.93) ${ }^{9}$.

\begin{tabular}{|c|c|c|}
\hline Regiōes PMM & Maior Homônima (Dó-maior) & Maior Paralela (Mib-maior) \\
\hline$t$ & Dó-menor & Mib-menor \\
\hline sd & Fá-menor & Láb-menor \\
\hline v-menor & Sol-menor & Sib-menor \\
\hline
\end{tabular}

Ex.31 - Regiões para Permutabilidade entre Maior e Menor à partir do alargamento das relações para a Maior Homônima e a Maior Paralela (exemplo em Dó menor). 
No Ex.32 ilustramos um prolongamento da função da fundamental sobre o ll grau. Primeiramente, consideramos as fundamentais omitidas: o segundo acorde do c.5 normalmente seria cifrado como Ab7, supondo um movimento cadencial para o Db7M. Porém, esse acorde pode ser visto como Transformação do segundo grau com baixo na quinta diminuta e fundamental omitida e, assim, o Db7M pode ser visto como um acorde de Sexta Napolitana. Essa análise se fundamenta na percepção do trecho produzindo a Progressão II - V - I, de forma que a fundamental Réb atue como emprestada por Permutabilidade Maior/Menor. Entende-se que todos os acordes transformados do trecho em questão possuem a função de II grau. Assim, esse exemplo é analisado como Cadência Enriquecida, pois o objetivo tonal da cadência é alcançado após a prolongamento da função do II grau dirigindo-se ao V7. Observamos que esse caso de prolongamento da fundamental contou com a utilização de: (1) cromatismos no nível da substituição; (2) consideração das fundamentais omitidas e; (3) consideração de cromatismo no nível das fundamentais com acordes emprestados por Permutabilidade Maior/ Menor, como o acorde de Sexta Napolitana.

0 contexto da Cadência Enriquecida consiste, basicamente, na utilização de recursos de expansão, tais como: Prolongamento de uma fundamental e Transformações remotas adicionadas às possibilidades da Permutabilidade entre Maior e Menor, dentro da cadência. Arno Roberto Von Buettner apresenta uma série de procedimentos de ampliação harmônica, no contexto da música popular, dentre eles, a Interpolação Harmônica, que "... acontece quando, numa cadência, o V7 torna-se IIm7, onde acorde interpolado está situado entre duas Dominantes" (BUETTNER, 2004, p.31), como no Ex. 33a.

Em outro exemplo, o autor demonstra o que chama de Interpolação da Interpolação Harmônica: "Existem casos em que o IIm7 ou V7 sub, podem estar entre o IIm7 e V7 originais, não afetando a realização da cadência, porque o último acorde antes da resolução sempre será o V7 original" (BUETTNER. 2004, p.36), mostrado no Ex. 33b.

\section{3- Contexto de Tonalidade Expandida}

A Tonalidade Expandida é, em certo sentido, o início do abandono da Monotonalidade, mas um contexto no qual transformações remotas e sucessões harmônicas ainda são compreendidas dentro de uma tonalidade. Segundo SCHOENBERG (2004, p.99), nesse contexto "tais progressões podem, ou não, produzir modulações ou estabelecer as diversas Regiões", funcionando como enriquecimento da harmonia. DUDEQUE (2005, p.123) afirma que a monotonalidade, vista já como Tonalidade Expandida, "encontrou um limite em seu desenvolvimento, resultando em seu abandono como principio geral organizador das relações tonais". Desta forma, os dois conceitos Tonalidade Flutuante e Tonalidade Suspensa, dentro da Tonalidade Expandida, "reforçam a desestabilização do centro tonal, e consequentemente, o abandono da monotonalidade". Concluindo, poderiamos admitir que a Tonalidade Expandida é uma prática que tem seu início a partir da Monotonalidade, e encontra seu fim na Tonalidade Flutuante ou na Tonalidade Suspensa.

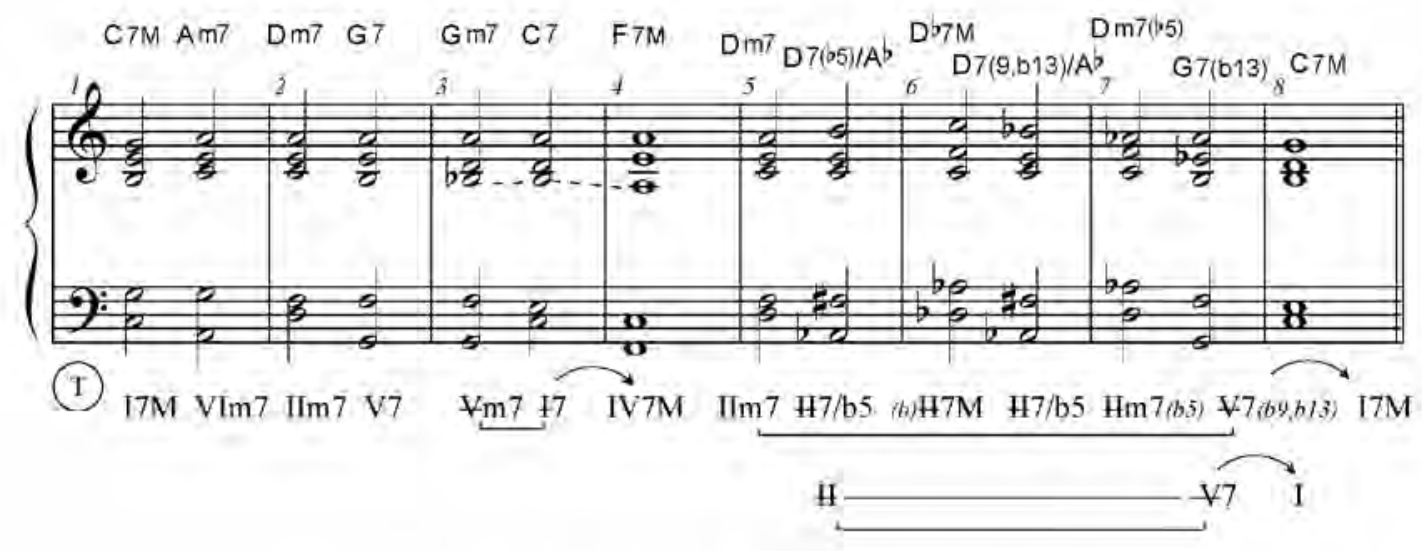

Ex.32 - Trecho com Prolongamento da função da fundamental sobre o II grau.
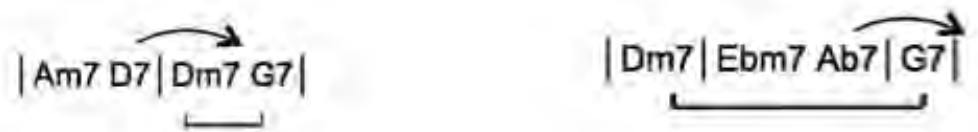

Ex.33a, b - Interpolação harmônica 
Nos vários exemplos utilizados em FEH, Schoenberg caracteriza a Tonalidade Expandida com a ocorrência de transformações que levam a desvios de Regiões muito remotas. Ele encontra exemplos na música de compositores desde o Barroco, como Bach (SCHOENBERG, 2004, p.102) ou na música clássica descritiva, como a de Schubert (SCHOENBERG, 2004, p.103), que contem modulações "extravagantes", como da tônica menor [t] (Dó menor), para a mediante menor da Dominante [mD] (Si menor). Schoenberg cita exemplos de Tonalidade Expandida, como a inclusão da Sexta Napolitana e uso de Regiões no interior dos temas estruturais de uma obra. Na sua análise das Variações Diabelli de Beethoven (SCHOENBERG, 2004, p.114-121), ele demonstra algumas dificuldades na interpretação de alguns trechos para se estabelecer Regiões. Em passagens da música de Dvorák, Grieg e Bruckner (SCHOENBERG, 2004, p.122), ele demonstra a ocorrência de acordes de passagem, suspensões e notas de passagem (inclusive sem resolução), explicando como trechos de análise problemática pode ser compreendidos sempre na Região da Tônica. Em um trecho de Reger (SCHOENBERG,2004, p.125), ele demonstra a ocorrência de acordes incompletos. No exemplo 113 que criou (SCHOENBERG, 2004, p.126), ele mostra como classificar as Regiões distantes. Já no seu exemplo 114 (SCHOENBERG, 2004, p.127), analisa trechos nas tonalidades homônimas simultaneamente $[t / T]$.

Acordes Vagantes e Escalas Alteradas e Simétricas (ou Sistema de Correspondências entre Acordes Vagantes): Finalmente, dentro do contexto da Tonalidade Expandida, buscamos uma adaptação do conceito de Acordes Vagantes com o conceito de Escala de Acorde (GUEST, 1996, p.49), utilizado por improvisadores e arranjadores na Música Popular ${ }^{10}$. Através das Escalas de Acorde Simétricas Octatônica e Hexafônica; e dos Modos da Escala Menor Melódica, procuramos "gerenciar" as correspondências entre acordes vagantes. Aventamos a possibilidade de ampliação desta rede a partir dos "Modos de Transposição Limitada" de Messiaen (dos quais a octatônica e a hexafônica fazem parte), e de modos e acordes de escalas "Diatônicas Alteradas" (MILLER, 1996, p.115-124) como a Maior Harmônica e Menor Melódica \#5.

Devido ao caráter múltiplo das estruturas vagantes, ou seja, a possibilidade de serem representados por vários acordes, a identificação da verdadeira função (isto é, da fundamental) de tais acordes nem sempre é explicitada pela cifra. Analisaremos primeiramente os acordes

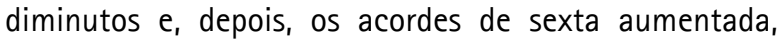
com o objetivo de estabelecer suas correspondências, buscando quais outros acordes seriam também representados pela estrutura analisada. Demonstraremos como essas correspondências podem ser organizadas por uma espécie de sistema derivado das Escalas de Acordes ${ }^{11}$. Com a associação de um acorde à uma Escalas de Acorde obtêm-se a possibilidade de uma gama maior de alterações. A escala correspondente a um determinado acorde deve conter suas notas estruturais, chamadas de Notas do Acorde (fundamental, terça, quinta e sétima), e a extensão (nona, décima primeira e décima terceira) do acorde que serão as Notas de Tensão. Algumas escalas oferecem alterações específicas de notas de tensão e notas estruturais, ao que chamamos aqui de Gama de Alterações. A cifra é um elemento determinante na visualização dessa relação entre escala e acorde. Normalmente, a indicação das Gamas de Alterações encontra-se entre parênteses ao lado da cifra, como por exemplo: $A b 7(b 9$, \#11,13). TINÉ (2002) propõe a associação do acorde de Sexta Germânica à Escala Octatônica.

A possibilidade de outras dissonâncias pode derivar de duas escalas simétricas usadas pelos improvisadores para estes acordes: pode

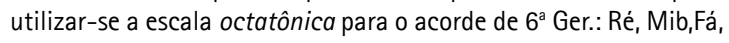
Fá\#, Sol\#, Lá, Si, Dó, tendo como possibilidade a ga aumentada, e a escala hexafônica para o acorde de $6^{\text {a }}$ Fr: Ré, Mi, Fá\#, Sol\#, Sib, Dó, tendo como possibilidade a $9^{a}$ maior (TINÉ, 2002, p.10).

Esse sistema de correspondência de acordes que propomos indica as múltiplas tendências possiveis a estes acordes em formar progressões ou sucessões. Indica também padrões de transformações para o acorde de Sétima da Dominante e para o acorde Meio Diminuto.

\section{Acorde de Sétima Diminuta e os Acordes de Sexta Aumentada e Dominantes Alteradas:}

0 acorde de Sétima Diminuta é o primeiro tipo de Acorde Vagante demonstrado em Harmonia. É apresentado como possibilidade de imitação do modelo cadencial VII - I da Escala Menor Harmônica.

A introdução sistemática, de acordes estranhos à escala pode continuar, (...), tentando-se transplantar também para o acorde de sétima diminuta para onde ele não ocorre naturalmente. Para isso interessa, em primeiro lugar, apresentá-lo sobre os mesmos graus que façam lembrar um VII grau do modo menor, pelo fato de apresentar um passo de segunda menor ascendente em direção ao próximo grau fundamental próprio da escala (SCHOENBERG, 1999, p.282).

Assim, para cada grau diatônico, existirá um acorde de sétima diminuta situado uma segunda menor abaixo.

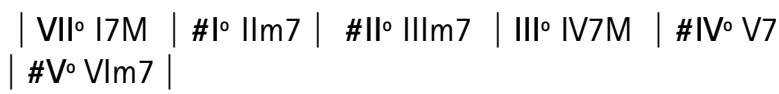

É aqui que Schoenberg afasta a possibilidade de transformação dos sons fundamentais, em favor da possibilidade de uma fundamental omitida. Por isso analisa os acordes diminutos como acordes com sétima menor e nona abaixada, e fundamental omitida. A verdadeira fundamental desse acorde encontra-se sobre o grau diatônico situado uma quarta abaixo do grau de resolução. No Ex.34, o acorde de sétima diminuta "C\#", estranho à tonalidade de Dó maior, situado uma segunda menor abaixo do IIm7 (Dm7), corresponde ao acorde de Dominante secundária com nona abaixada situado uma quarta abaixo do IIm, ou seja $\forall 77(b 9)$ (A7(b9)). Portanto, o acorde diminuto, 
corresponde a um acorde de sétima da Dominante com nona abaixada, com fundamental omitida.

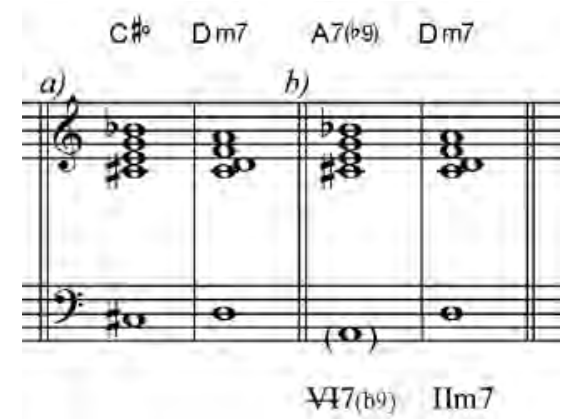

Ex.34 - Acorde diminuto visto como dominante com fundamental omitida.

A estrutura do acorde de sétima diminuta é simétrica, ou seja, compõe-se de intervalos idênticos. Por isso, suas inversões também geram estruturas idênticas, de modo que um acorde de sétima diminuta corresponda a um total de quatro acordes distantes entre si por uma terça menor. Assim, compreende-se que o sistema possui

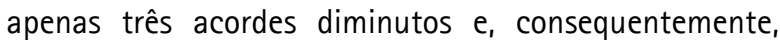
suas correspondências (incluindo-se as enarmonias ${ }^{12}$ ). Por exemplo:

a) $\mathrm{CH}^{\circ}, \mathrm{E}^{\circ}, \mathrm{G}^{\circ}, \mathrm{B} b^{\circ}$ e seus correspondentes $\mathrm{A} 7(b 9)$, $\mathrm{C} 7(b 9), \mathrm{E} b 7(b 9), \mathrm{G} b 7(b 9)$.

b) $\mathrm{D}^{\circ}, \mathrm{F}^{\circ}, \mathrm{A} b^{\circ}, \mathrm{B}^{\circ}$ e seus correspondentes $\mathrm{B} b(b 9)$, $\mathrm{Db7}(b 9), \mathrm{E7}(b 9), \mathrm{G} 7(b 9)$.

c) $\mathrm{E}^{\circ}, \mathrm{G} b^{\circ}, \mathrm{A}^{\circ}, \mathrm{C}^{\circ}$ e seus correspondentes $\mathrm{B}(b 9)$, D7(b9), F7(b9), Ab7(b9).

Os acordes de sexta aumentada são casos típicos de acordes vagantes. São obtidos como resultado da transformação dos graus diatônicos em Dominantes Secundárias com a quinta e nona abaixadas. Podem assumir três configurações: Acorde aumentado de quinta e sexta, chamado de Acorde de Sexta Germânica (ou Sexta Alemã); Acorde aumentado de terça e quarta (acorde de Sexta Francesa), e Acorde aumentado de sexta (acorde de Sexta Italiana). Na teoria da harmonia na música popular, esses acordes são analisados como substitutos da Dominante. Abaixo fazemos uma discussão mais detalhada sobre essas configurações no contexto da música popular, e seu potencial de tratamento como Tonalidade Expandida.

O Acorde de Sexta Germânica e a Escala Octatônica: É a primeira derivação do acorde de sexta aumentada apresentada por Schoenberg em Harmonia, demonstrado através da transformação do "acorde de quinta e sexta sobre o II grau do modo maior, elevando-se a terça e a fundamental, e rebaixando-se a quinta" (SCHOENBERG,1999, p.352). Em outras palavras, o acorde $\mathrm{Dm} 7 / \mathrm{F}$ é transformado e assume a configuração de D7(b9, b5)/F\# com a fundamental Ré omitida. Essa configuração enarmonizada corresponde ao Ab7/Gb. Numa primeira análise, o acorde $A b 7 / G b$ permite a adição da nota Ré (omitida), e uma vez que já contém a quinta justa, o Ré surge como nota de tensão "\#11". Assim, esse acorde seria potencialmente um Ab7 (\#11)/Gb. Seguindo o raciocínio apresentado mais acima sobre a relação escala/acorde, relacionamos esta estrutura à Escala Octatônica, que oferece a seguinte Gama de Alterações.

a) $\quad \mathrm{X} 7(69, \# 9, \# 11$, ou 65,13$)$

A Escala Octatônica é uma escala simétrica que promove a correspondência de vários acordes em intervalos de um tom e meio (terça menor ou segunda aumentada). $\mathrm{Na}$ música erudita normalmente diz-se que há apenas dois tipos de escala octatônica: Tipo A: que começa com tom-semiton (Dó-Ré-Mib......) e Tipo B que começa com semiton-tom (Dó- Réb - Mib.....) e suas diversas transposições ( $12+12=24$ sem contar os enarmônicos). Essas escalas Tipo a e Tipo B poderiam têm equivalência na música popular com as escalas dom-dim (dominantediminuta; cuja segunda nota é a nona maior [por exemplo Ré se estivermos em Dó Maior]) e dim-dom (diminutadominante, cuja segunda nota é a nona menor [por exemplo Ré b se estivermos em Dó Maior]). No entanto, se levarmos em consideração correspondência entre os acordes diminutos e os acordes dominantes demonstrada mais acima, teremos três escalas (Ex.35) para cobrir todas as possibilidades do cromático de 12 sons. 0 Ex.36 mostra os Acordes Diminutos correspondentes aos Acordes de Sétima da Dominante com a nona abaixada e fundamental omitida.

Assim, o acorde vagante diminuto e o acorde de Sexta Germânica são correspondentes se relacionados à escala octatônica. Tomemos como exemplo um acorde vagante cifrado como um $D^{\circ}$. Relacionando-o à $3^{\text {a }}$ coleção octatônica, ele torna-se equivalente aos acordes dominantes $\mathrm{C} \# 7$, ou E7, ou qualquer outro desta coleção, podendo assumir suas propriedades funcionais. Além disso, com tal associação, o D passa a ter como notas de tensão disponíveis, todas as notas da gama, podendo ser utilizado como $D^{\circ} 7 \mathrm{M}(9,11$, b13). Da mesma forma, um acorde dominante associado a esta coleção terá como configuração disponivel, por exemplo, E7 (b9, \#9, \# 11, 13). O Acorde de Sexta Francesa e Escala Tons Inteiros (ou
Escala Hexafônica):
0 Acorde de Sexta Francesa pode ser demonstrado
através da transformação do acorde de terça e quarta
sobre o II grau do modo maior ou menor, elevando-se
a terça e rebaixando-se a quinta (SCHOENBERG, 1999,
p.365). Em Dó maior, o acorde Dm7/A é transformado e
assume a configuração de D7(b5)/Ab. Continuando com
a associação de escalas às configurações dos acordes de
Sexta Aumentada, notamos que, no caso do acorde de
Sexta Francesa, não existe uma determinação quanto à
nona. TINÉ (2002) sugere a associação desse acorde à
Escala Hexafônica, também conhecida como Escala de
Tons Inteiros. A escala simétrica Hexafônica é formada 
por sucessão de intervalos de um tom, e por isso se reduz a duas formas e suas transposições (Ex.37). A Escala Hexafônica promove a seguinte gama de alterações a um acorde vagante:

- $\quad$ X7 (9,\#11 ou b5, \#5 ou b13)

0 Acorde de Sexta Italiana, a Escala Lídia (b7) e a Escala Alterada:

Exemplificado por Schoenberg através do II grau do modo maior com a quinta abaixada e fundamental omitida. Em outras palavras: Dm7/A transformado em D7(b5)/ Ab com a fundamental omitida. Essa configuração confunde-se com Ab7 sem a quinta. Pelo fato de não apresentar nenhuma exigência sobre a alteração da nona e da quinta, ele permite ser associado a dois modos da escala menor melódica: (1) aquele sobre o IV grau, conhecido como modo Lídio b7, ou Mixolídio \#11; e (2) aquele sobre o VII grau, conhecido como modo Superlócrio. No modo Lídio b7, ou Mixolídio \# 11 (Ex.38), o Acorde Vagante pode assumir a seguinte gama de alterações: X7 $(9, \# 11,13)$.

0 modo sobre o VII grau da Escala Menor Melódica é o modo Superlócrio e corresponde a um acorde meio diminuto. Porém, na prática da música popular esse modo é denominado Escala Alterada e é associado a um acorde de Sétima Dominante conhecido na teoria da música popular como Acorde Alterado. TINÉ (2002) explica que, para a consideração dessa escala, :

(...) não se considera uma sobreposição de $3^{\text {as }}$, mas de $4^{\text {as }}$ (Sol\#, Dó, Fá\#, Si, Mi, Lá, Ré), gerando um acorde Dominante (enarmonizando do em Si\#) com $9^{a}$ aumentada (enarmonizando Si em Lá\#\#), $13^{\text {a }}$ menor, $9^{a}$ menor e $11^{\text {a }}$ aumentada, com função de $V$ (Dominante), não de Lá (neste exemplo), mas de Dó\# (maior ou menor) (TINÉ, 2002, p.5).

O Ex.39a mostra: (1) o modo Superlócrio e seu Acorde Meio Diminuto correspondente dentro do sistema de referência tercial; (2) a Escala Alterada e seu Acorde de Sétima da Dominante Alterado, no sistema de referência quartal.

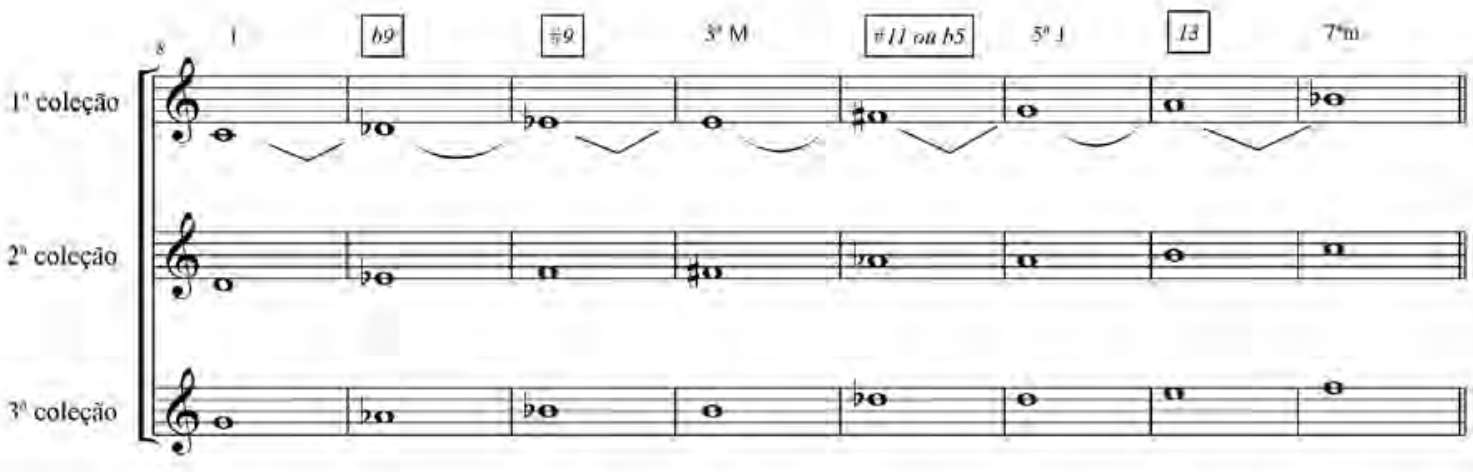

Ex.35 - Coleções Octatônicas e notas disponiveis em um acorde dominante C7.

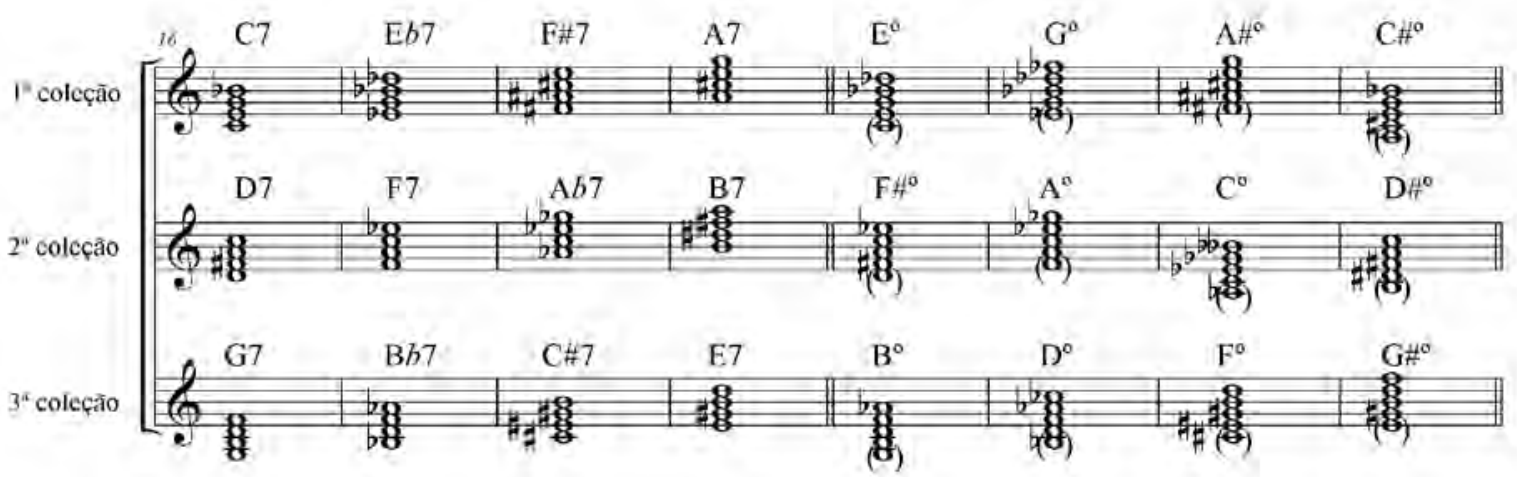

Ex.36 - Acordes Diminutos correspondentes aos Acordes de Sétima da Dominante com a nona abaixada e fundamental omitida. 


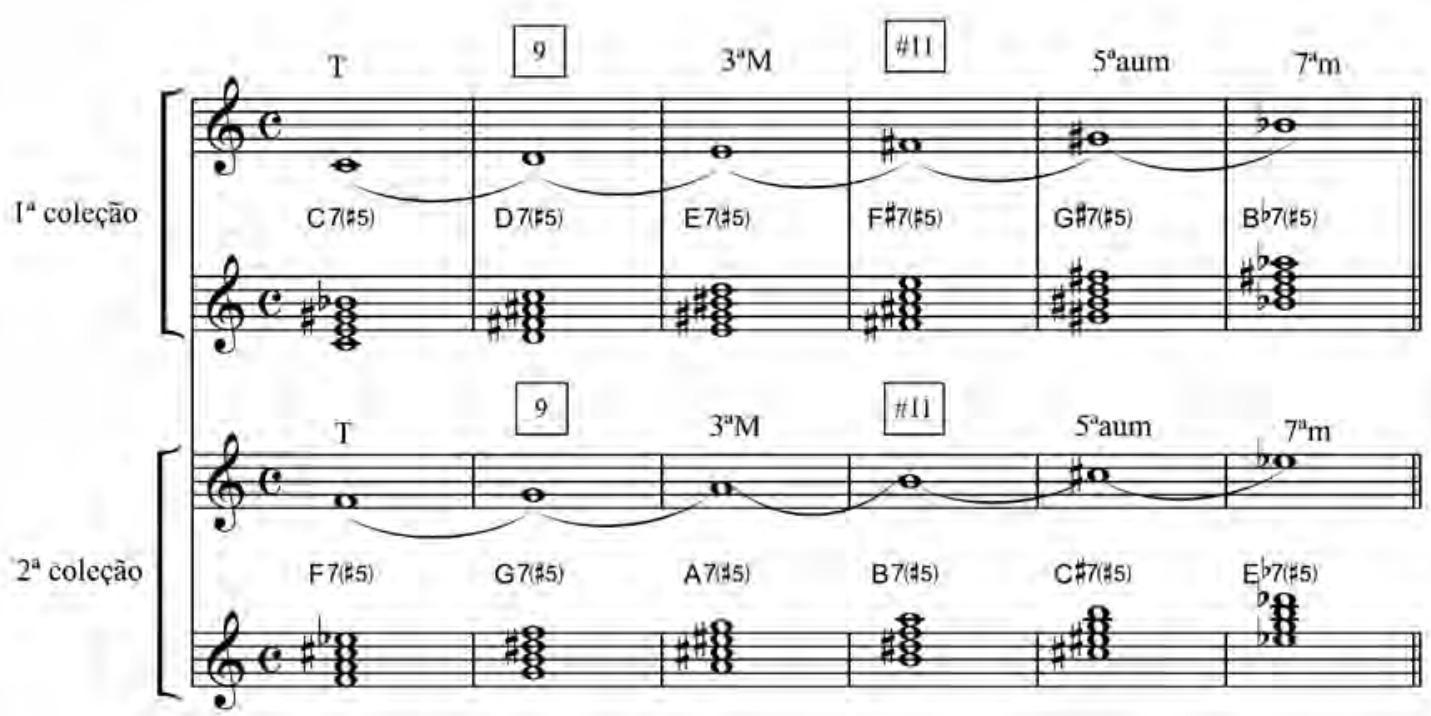

Ex.37 - Acordes vagantes correspondentes, segundo as duas Coleções Hexafônicas (Tons inteiros).

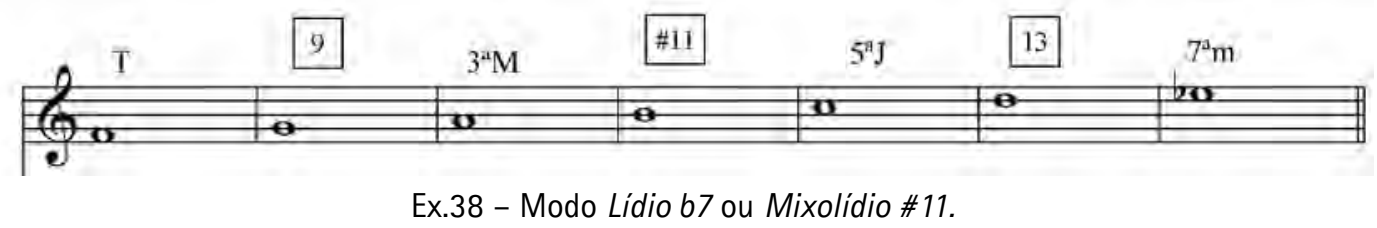

Com a inclusão do VII grau pelo sistema quartal, obtemos uma correspondência importante para o acorde de Sexta Italiana. 0 acorde de Sexta Italiana pode ser prolongado com nona, décima primeira aumentada e décima terceira, e assim assumir correspondência direta com um acorde cuja fundamental esteja à distância de um trítono. Este novo acorde pode ser prolongado com as notas da escala alterada, isto é, a nona abaixada e aumentada, a décima primeira aumentada e a décima terceira abaixada: (a) IV7 $(9, \# 11,13)$ ou IV7 $(9,65,13)$; (b) VII7 (alt) ou VII7 $(69, \# 9, \# 11$ ou $65, b 13$ ou \#5). 0 Ex.40 ilustra a correspondência entre 0 modo Lídio b7 e a Escala Alterada advindos de uma mesma escala Menor Melódica.

0 Ex.41 mostra as correspondências dos Acordes Dominantes relacionados ao modo Lídio b7 e à Escala Alterada. Com essas observações podemos propor que os Acordes Vagantes possam ser regidos por um sistema de relações que atua paralela e simultaneamente à tonalidade. Esse sistema, que aqui chamamos de Sistema de Correspondências dos Acordes Vagantes, faz com que os acordes de Sexta Aumentada assumam determinados padrões de configuração (Gama de Alterações) que serão automaticamente relacionadas à coleção Octatônica; ou à coleção Hexafônica; ou aos modos da Escala Menor Melódica.

\subsection{1 - Procedimentos de Expansão Harmônica}

Dentre os Procedimentos de Expansão Harmônica mais comuns estão a Imitação dos Modelos Cadenciais e a Omissão do Caminho. A primeira possibilidade sugere que qualquer um desses acordes possa ser precedido pelo IIm7 ou Ilø e (b)II7M dos seus correspondentes, segundo os modelos cadenciais II $-\mathrm{V}$. $^{13}$

O Acorde de Sexta Germânica e as Coleções Octatônicas: 0 Ex.42 mostra os acordes correspondentes de F7 na primeira coluna, e os respectivos segundos graus cadenciais na segunda coluna.

No Ex.43 (a, b e c), mostramos como a progressão | F7 | $\mathrm{Bbm} \mid$ pode sofrer duas Expansões Harmônicas: primeiro para | Cm7 F7 | Bbm | e, depois, para | Cø F7 | Bbm |. 


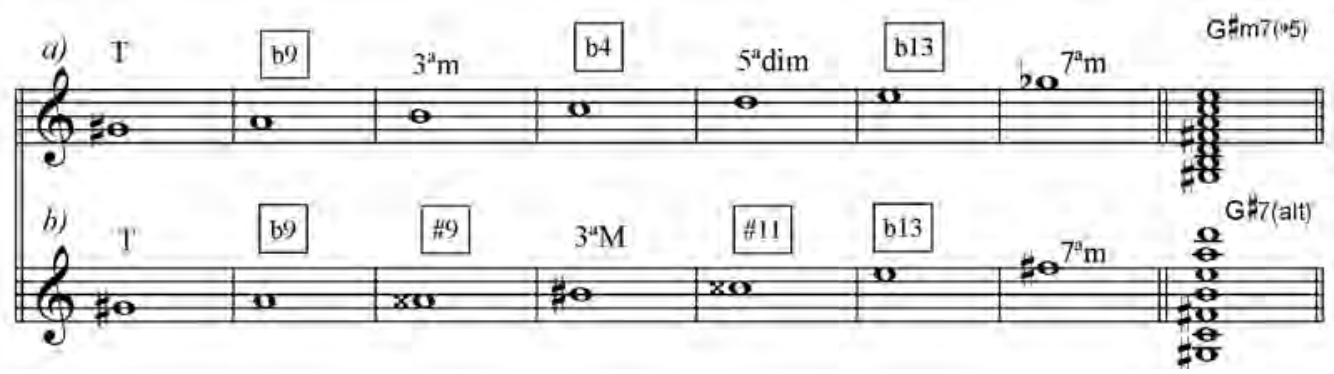

Ex.39 a e b - Modo Superlócrio e a Escala Alterada, com respectivos acordes Meio Diminuto G\#m7(b5) e Sétima da Dominante Alterado G\#7(alt).

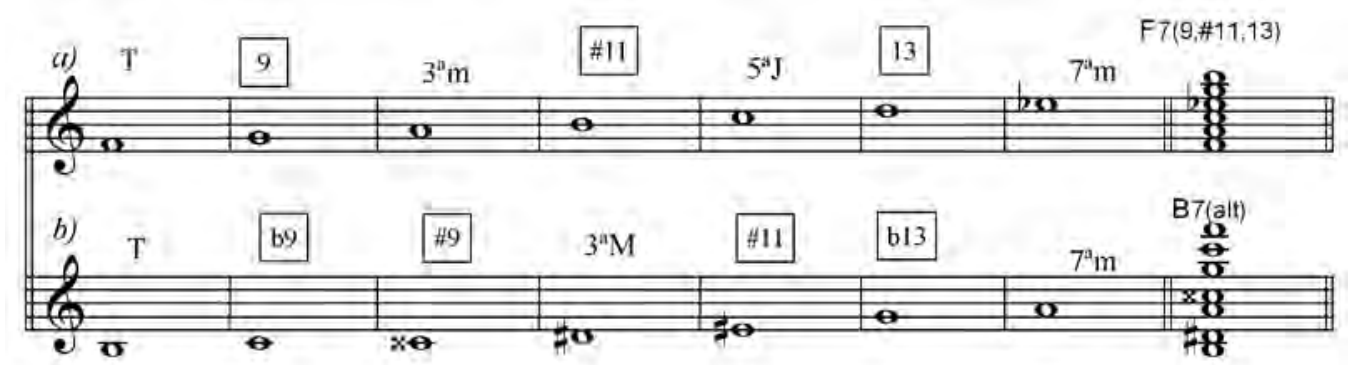

Ex.40 - Correspondência entre o modo Lídio b7 e Escala Alterada advindos de uma mesma escala Menor Melódica, com respectivos Acorde Lídio b7 F7(9, \#11,13) e Acorde Alterado B7(alt).

\begin{tabular}{|c|c|}
\hline IV7 $(9, \# 11,13)$ ou $(9, b 5,13)$ & VII7 (alt) ou $(b 9, \# 9, \# 11$ ou $b 5, b 13$ ou \#5) \\
\hline C7 & F\#7 ou $\mathrm{Gb7}$ \\
\hline F7 & B7 \\
\hline Bb7 ou A\#7 & E7 \\
\hline Eb7 ou D\#7 & A7 \\
\hline Ab7 ou G\#7 & D7 \\
\hline Db7 ou C\#7 & G7 \\
\hline Gb7 ou F\#7 & C7 \\
\hline Cb7 ou B7 & F7 \\
\hline E7 & Bb7 ou A\#7 \\
\hline A7 & Eb7 ou D\#7 \\
\hline D7 & Ab7 ou G\#7 \\
\hline G7 & Db7 ou C\#7 \\
\hline
\end{tabular}

Ex.41 - Acordes Vagantes correspondentes segundo os graus IV7 e (b)VII7 da escala Menor Melódica.

\begin{tabular}{|c|c|}
\hline “X7" (F7) & IIm7 ou Ilø (Cm7 ou Cø) \\
\hline$(B 7)$ & F\#m7 ou F\#ø \\
\hline$(\mathrm{Ab7})$ & Ebm7 ou Ebø \\
\hline (D7) & Am7 ou Aø \\
\hline
\end{tabular}

Ex.42 - Possibilidades de expansão de um Acorde Dominante de Sétima (F7) relacionado à uma Coleção Octatônica. 
0 Ex.44 ( $a$, b e c) mostra seis possibilidades de Expansão Harmônica, nas quais o Acorde Vagante F7 com configuração relacionada à Coleção Octatônica pode ser precedido pelo II grau dos seus correspondentes. Esta expansão caracteriza-se por acrescentar o passo cadencial que representa a força da Subdominante. Por isso, a relação (dentro da cadência) do acorde expandido com o Dominante Vagante, pode ser bem representada pelo colchete tracejado. 0 acorde pode ser analisado como grau transformado com auxílio do algarismo cortado (por exemplo: VIm7) e da alteração em parênteses, se for o caso (por exemplo: (\#)Vॠø), seguido pelo colchete tracejado. Observamos que 0 colchete tracejado é utilizado na sinalização analítica de CHEDIAK (1986, p.101), apenas para indicar II cadencial do subV7. Observamos ainda que o acorde vagante F7 assumiu diferentes "roupagens", ou padrões dentro das possibilidades oferecidas pela Coleção Octatônica, que seriam as combinações das notas nona abaixada, nona aumentada, décima primeira aumentada ou quinta diminuta e décima terceira maior (b9, \#9, \#11 ou b5, 13), além da fundamental, terça maior e sétima menor $(1,3,7)$. No Ex.44a, o padrão é $F 7(b 9, \# 11,13)$ e $F 7(\# 9, \# 11)$. Já no Ex.44b, o padrão é $\mathrm{F} 7(\# 9, \# 11)$ e $\mathrm{F} 7(69,13)$

O Acorde de Sexta Francesa e a Coleção Hexafônica (ou Escala de Tons Inteiros):

Seguindo o mesmo procedimento, temos que todos os acordes aumentados de Sexta Francesa relacionados a uma coleção hexafônica podem ser precedidos pelos segundos graus cadenciais $\mathrm{m} 7$ ou $\emptyset$ de seus correspondentes. 0 Ex.45 mostra o acorde $F 7(\# 5)$ e seus correspondentes associados à Coleção Hexafônica ( G7, A7, B7, C\#7 ou D\#7).
0 Acorde de Sexta Italiana e os Modos da Escala Menor Melódica:

Existem duas possibilidades de expansão nesse caso. Primeiro, o acorde pode ser precedido pelo seu II grau, seguindo o modelo cadencial IIm7 -V7 ou IIø - V7. Como, por exemplo | F7 | Bbm | com expansão para | Cm7 F7 | $\mathrm{B} b m \mid$ ou para $|\mathrm{C} ø \mathrm{~F} 7| \mathrm{B} b \mathrm{~m} \mid$. Segundo, o acorde pode ser precedido pelo II grau do seu correspondente (neste caso, B7). Como, por exemplo, |F7 | Bbm | com expansão para | F\#m7 F7 | Bbm | ou para |F\#ø F7 | Bbm |.

Diferente das escalas octatônica e hexafônica, que produzem um mesmo tipo de acorde em seus graus, a escala menor melódica produz diferentes tipos de acordes (Ver Ex.3b). Uma expansão possivel e mais radical é considerar todos esses acordes como correspondentes para a expansão. LEVINE (1989, p.73-75) explica que as notas da escala menor melódica são intercambiáveis para todos os acordes de seu campo harmônico por que ela não possui "notas evitadas", como é o caso da escala maior. Com isso, temos que os acordes da menor mélodica, a saber: Xm7M; Xm7(b9);X7M(\#5);X7(\#11); X7(b13); Xø(9); X7(alt); são correspondentes pois podem ser associados a uma mesma escala menor melódica. Por exemplo, Eb7M(\#5) é blll grau de Dó menor melódica, assim com F7(\#11) é o IV grau e B7(alt) é o VII grau. Estas relações permitem a expansão do exemplo do parágrafo anterior,

|F7 | Bbm |, em:a) | Eb7M(\#5) | Bbm |; b)| Cm7 Eb7M(\#5)

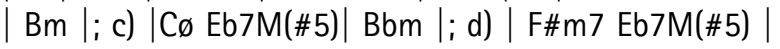
$\mathrm{Bbm} \mid$; e) | F\#ø Eb7M(\#5) | Bbm |.

\section{A Omissão do caminho}

A Omissão do Caminho é um procedimento de expansão que deriva do princípio da Abreviação dos Passos das Fundamentais. ${ }^{14}$ Schoenberg apresenta essa concepção

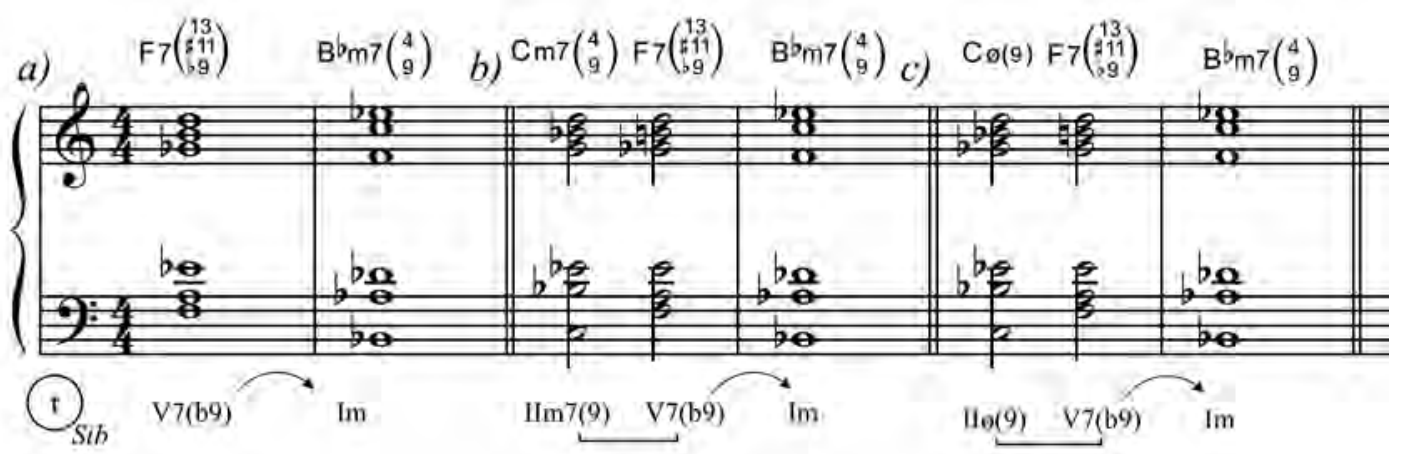

Ex.43 (a, b e c) - Duas possibilidade de Expansão Harmônica por adição do II grau cadencial. 

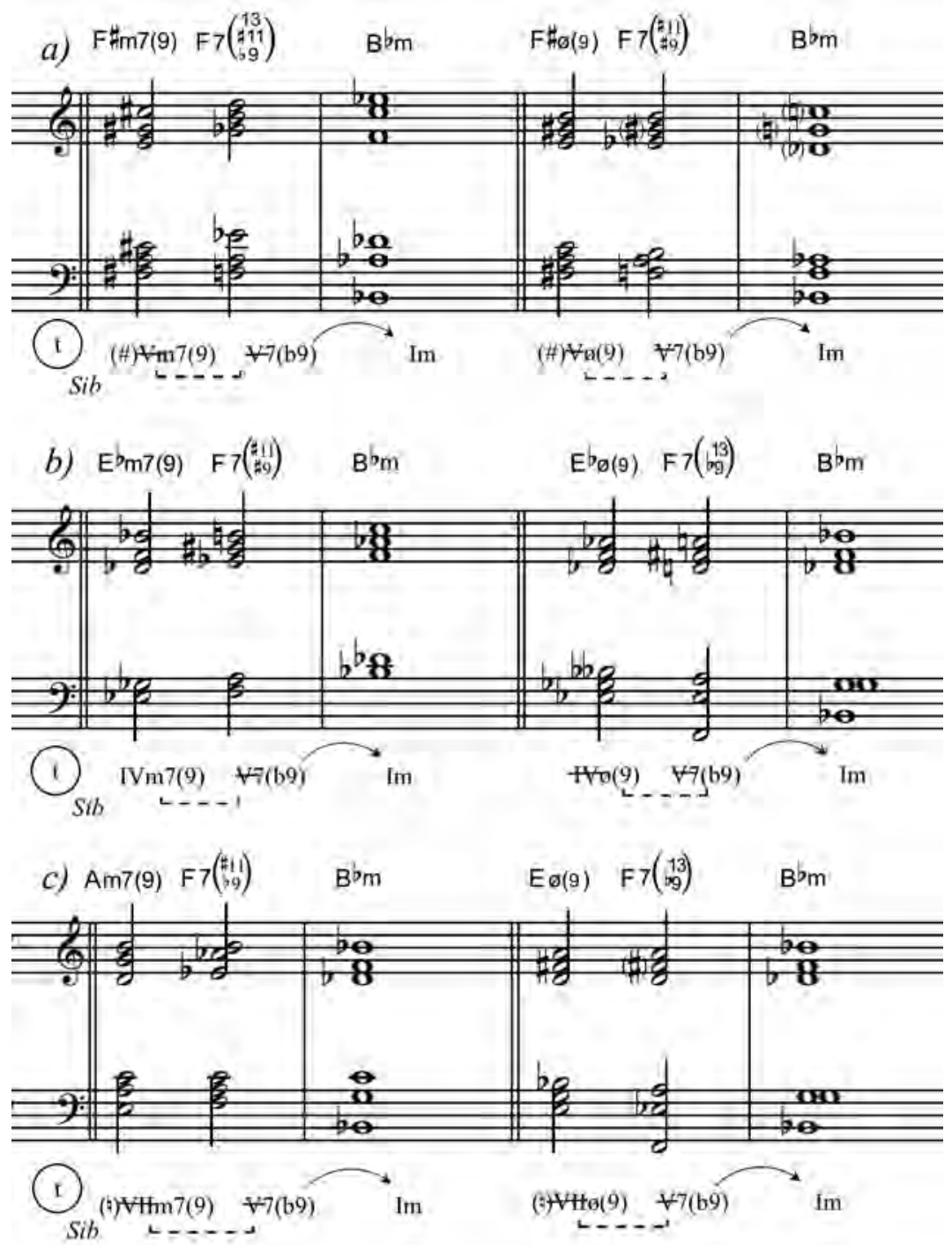

Ex.44 (a,b e c) - Seis possibilidades de Expansão Harmônica de F7 - Bbm por adição do II grau cadencial dos Acordes Vagantes correspondentes.

\begin{tabular}{|c|c|}
\hline "X7"[F7(\#5)] & IIm7 ou llø (Cm7 ou Cø) \\
\hline G7(\#5) & Dm7 ou Dø \\
\hline$A 7(\# 5)$ & Em7 ou Eø \\
\hline B7(\#5) & F\#m7 ou F\#ø \\
\hline C\#7(\#5) & G\#m7 ou G\#ø \\
\hline$D \# 7(\# 5)$ & A\#m7 ou A\#ø \\
\hline
\end{tabular}

Ex.45 - Possibilidades de expansão de um Acorde Dominante relacionado a uma Coleção Hexafônica. Nota: Para todos os acordes acima valem suas enarmonias. 
em Harmonia, no tópico "Abreviação de viragens através da omissão do caminho" (SCHOENBERG, 1999, p.500). Ao longo de seu raciocínio, Schoenberg conclui que, dentro da cadência, o passo cadencial desempenhado pela Dominante pode ser abreviado, ficando a intenção cadencial subentendida apenas com o acorde com tendência à função de Subdominante.

\begin{abstract}
(..) é uma semelhante abreviação aquele tratamento da Sexta Napolitana que traz diretamente o V grau. (..) As conclusões plagais talvez sejam também algo semelhante. Talvez por isso soem imperfeitas, porque alguma coisa foi eliminada. A saber: em vez de IV-V-I ou II-V-I coloca-se IV-I e II-I. (...) No geral, abreviações desse gênero somente podem ser efetuadas em encadeamentos que possuam uma função determinada; logo, sobretudo nas cadências (SCHOENBERG, 1999, p.500-501).
\end{abstract}

Usemos com exemplo, a progressão | F7 | Bbm |. 0 acorde dominante $F 7$, se associado à Coleção Octatônica, terá como configuração possivel F7(b9, $\# 9$,\#11,13) e como acordes correspondentes. (neste caso: Ab7; B7; D7). Aplicando-se o procedimento de Omissão do Caminho, a progressão pode ser expandida com o II grau cadencial de B7: | F\# m7 | Bbm | ou | F\#ø $|\mathrm{Bbm}|$; expandida com o II grau cadencial de Ab7: | Ebm7 | Bbm | ou | Ebø I de B7: | Bbm | ; expandida com o II grau cadencial de D7: |Am7 | Bbm | ou | $\mathrm{A} \varnothing|\mathrm{Bbm}|$. Os Acordes Meio Diminutos podem ser mais apropriados para desempenhar essa função, se associados ao modo Lócrio 9, isto é, ao VI grau da escala menor melódica, com a configuração $X \emptyset(9,11, b 13)$. Essa expansão leva a uma relação bastante remota, pois faz com que o Acorde Meio Diminuto seja considerado um Acorde Vagante, organizado por uma coleção diferente da Octatônica (no caso a menor melódica). Porém, sua relação com os acordes dentro da cadência provém das correspondências da Octatônica.

\section{4 - Contexto de Tonalidade Flutuante}

Segundo DUDEQUE (2005, p.124), a Tonalidade Flutuante ocorre quando se considera a existência de duas tônicas em um contexto tonal ambíguo. Assim, sua principal característica seria a incerteza, ou seja, a existência de trechos que podem ser analisados em duas Regiões. Schoenberg demonstra o papel dos acordes vagantes dentro da Tonalidade Flutuante:

\footnotetext{
Se a tonalidade deve flutuar, terá, em algum ponto, de estar firme. Porém, não tão firme que não possa movimentar-se com soltura. Para isso são adequadas duas tonalidades que possuam alguns acordes em comum, por exemplo, a Sexta Napolitana ou o aumentado de quinta e sexta (SCHOENBERG, 1999, p.528).
}

Em seguida, Schoenberg fornece dois exemplos de relações entre Regiões que seriam adequadas para caracterizar a Tonalidade Flutuante: (a) T (Dó maior) e Np (Réb maior); sm (Lá menor) e DMb (Sib maior); (b) Deixando-se a T oscilar contra a relativa sm, e consequentemente, a $\mathrm{Np}$ contra sua relativa, o que gera novas relações: sm (Lá menor) e $\mathrm{Np}$ (Réb maior); e T (Dó maior) e vmb (Sib menor). Nesta última, o V7 da vmb - "F7" -, corresponde ao H7(b5) -
B7(b5) - , acorde de Sexta Italiana da Intermediária [sm]. Como comentado anteriormente, a Tonalidade Flutuante seria um caso particular de Tonalidade Expandida. Esse contexto pode fazer parte da estrutura da peça, ou ser encontrado apenas em trechos da música.

\section{5- Contexto de Tonalidade Suspensa}

Em Harmonia (1999), Schoenberg destaca duas características da Tonalidade Suspensa. Primeiro, seu aspecto melódico:

\begin{abstract}
Pelo que diz respeito à Tonalidade Suspensa, depende totalmente do tema. Este deve, através de suas viragens, fornecer o motivo para semelhante liberdade harmônica (SCHOENBERG, 1999, p.529).
\end{abstract}

Depois, a predominância de Acordes Vagantes:

\begin{abstract}
Sob o aspecto harmônico tratar-se-á aqui, quase que de forma exclusiva, de acordes nitidamente errantes. Qualquer triade maior ou menor poderia, ainda que de passagem, ser interpretadas, como se fosse em si uma tonalidade (SCHOENBERG, 1999, p.529).
\end{abstract}

Portanto, suspender a sensação de centro tonal através de Acordes Vagantes em relação ao aspecto melódico e temático é um procedimento que coloca o centro tonal dentro da possibilidade teórica das fundamentais omitidas. Além disso, esta aparente suspensão seria suavizada, ou unificada, com uma condução de vozes elaborada através de Variação Progressiva (conceito que será abordado no próximo artigo, às p.70-95 desse número de Per Musi). Essas considerações apontam sempre no sentido de que os conceitos harmônicos de Schoenberg permitiriam extrapolar os efeitos clichês de re-harmonização. As relações estabelecidas sempre apontam para um centro que, com a engenhosidade das possibilidades de Expansão e consequentemente, Flutuação e Suspensão, permitem que a tônica não apareça na peça (!) e, ainda assim, apresentar uma influência incontestável sobre suas relações harmônicas.

A prática da improvisação na música popular poderia se beneficiar da comparação que Schoenberg estabelece entre a utilização da Tonalidade Suspensa e as seções formais dos desenvolvimentos [Durchfuhrung] clássicos:

\begin{abstract}
Uma semelhança, não demasiado distante, já se tem nos desenvolvimentos clássicos, onde por certo o momento isolado exprime necessariamente uma tonalidade, mas tão desprendida que pode perder-se a qualquer instante (SCHOENBERG, 1999, p.529).
\end{abstract}

Os conceitos de Tonalidade Suspensa e Tonalidade Flutuante poderiam facilmente levar a generalizações ou interpretações enganosas, como por exemplo, na análise de uma peça que sugira modulações em sequência. Mas devemos ter em mente que esses conceitos são casos especiais de Tonalidade Expandida. Por outro lado, estes conceitos poderiam desempenhar um papel importante na elaboração de arranjos, como ferramentas práticas para o desenvolvimento de variações do tema e estrutura harmônica expostos nas lead sheets. 


\section{5 - Exemplos de articulação dos conceitos em lead sheets.}

Nos exemplos abaixo, ilustramos a articulação dos conceitos revisados ao longo desse artigo a partir de situações encontradas na lead sheet de 9 de Agosto de 1996 de Hermeto PASCOAL (2000a) e 14 de Novembro de 1996 de Hermeto PASCOAL (2000b) para uma possível realização dessas músicas. Uma das vantagens desta abordagem é facilitar a criação de linhas contrapontísticas na sua realização. Essas linhas dão uma alternativa à realização tradicional estritamente homofônica dos acordes, e mostram o direcionamento do discurso musical e o trânsito entre as Regiões. Assim, pode-se criar mais facilmente movimentos quasediatônicos ou cromáticos com vistas a uma realização com função centrípeta ou centrífuga do trecho.

\section{1 - Criação de linhas contrapontísticas para a realização da música 9 de Agosto de 1996 de Hermeto Pascoal}

Esta canção instrumental começa na t (Ré menor) com um prolongamento e uma cadência deceptiva até o c.7 (Ex.46). No c.9 o acorde cifrado como Bb458/ G5+7 (cifra especial de voicings criada por Hermeto) é analisado como Eb(add2)/G, acorde de Sexta Napolitana sobre o II grau (Ex.47). Desta forma, os c.7-9 parecem caracterizar uma Sucessão gerada pelo prolongamento do II grau da Região da t. Porém, embora todo esse trecho possa ser analisado como prolongamento do II grau através de transformações, a continuidade do discurso nos mostra que, no lugar de um possivel prolongamento, pode estar ocorrendo, na verdade, uma Progressão cujo destino parece ser a Região da $\mathrm{Np}$. 0 primeiro fator que sugere isso é a sequência $\mathrm{B} b 7 / \mathrm{A} b-\mathrm{E} b$ e $\mathrm{C} 7 / \mathrm{B} b$ - F/A nos c.8-10 (Ex.48). Este trecho parece delinear duas Regiões Intermediárias que se dirigem para a Região da Np, no c.12 (Ex.48). Essas Regiões estão sempre representadas pelo seu IV grau, e preparadas pelo I grau transformado com quinta abaixada, com baixo na sétima $\left[+7(b 5) / 7^{a}\right]$, respectivamente, a SM (Sib maior) e a SubT (Dó maior). Este acorde é utilizado como Acorde Vagante para conectar as Regiões da Np e da sm. Nos c.15 e 16 (Ex.49), a Região D (Lá maior) antecede o retorno da Região da t (Ré menor). No c.17, ocorre o acorde de Sexta Napolitana sobre o II grau transformado. A música se conclui sugerindo uma Região mais distante, a da S/T (Mi maior), e este distanciamento continua até a $\mathrm{mS} / T$ (Dó\# menor).

Nos c.5-6 do Ex.46, ocorre a utilização do $6^{\wedge}$ grau elevado seguido pelo $6^{\wedge}$ natural. Para Schoenberg, 0 sexto grau elevado é utilizado para fins cadenciais. Segundo o procedimento da Neutralização, o $6^{\wedge}$ grau elevado deve seguir ao sétimo grau elevado e este à tônica. Isso pode ser aproveitado no c.5 para criar uma linha contrapontística quase-diatônica ( $\mathrm{Od}$ ) ascendente, ligando a nota Lá à nota Ré. Enquanto isso, outra linha, cromática $(\mathrm{Cr})$ e descendente, é criada no baixo com as notas fundamentais Si, Sib e Lá.

0 Ex.47 mostra como aproveitar a concepção de Transformação para obter direcionamentos das vozes transformadas. 0 acorde do c.7 é interpretado como sus (b9), o que permite sua leitura como Ilø e V7. Com isso, a nota do baixo Lá desce para Sol de modo a configurar o acorde Eø/G. 0 acorde do c.8 foi analisado como transformação do II grau anterior da $\mathrm{t}$ através da elevação da terça Sol para Sol\#, isto é um E7(b5). Uma vez configurado como Acorde Vagante e que, com isso, passa a ser utilizado como Bb7(\#11). Assim, a nota Sol\# é enarmonizada como Láb e naturalmente segue sua nova tendência de resolução descendente para o Sol.

Observar que o movimento dessa linha foi obtido apenas com dados extraídos da análise. Assim, podemos tratar a primeira sequência de notas Lá - Sol -Sol\# como uma resolução indireta. No c.9, o acorde foi analisado como II grau transformado, por alteração da terça. Assim, a nota Mib é transformada em Mi natural. Mais uma vez, a configuração do acorde resultante é Vagante, que passa a funcionar como Dominante secundário do IV grau da Região subT, por transferência de função. Esse exemplo mostra

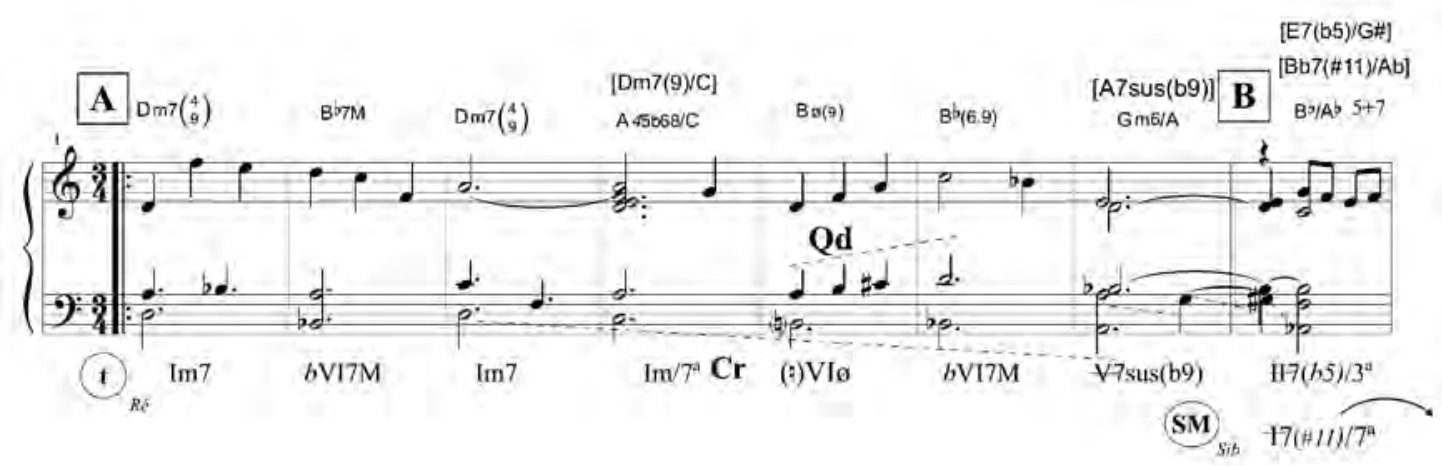

Ex.46 - criação de duas linhas contrapontísticas em 9 de Agosto de 1996 de Hermeto Pascoal. 
como os conceitos harmônicos schoenberguianos podem esclarecer as direções inerentes ou implícitas em determinadas vozes.

Para se obter um direcionamento da(s) voz(es) transformada(s) por meio da própria cifra, observamos dois passos. Primeiro, a direção ascendente ou descendente é determinada pela transformação indicada na cifra da Região de origem. Segundo, com base na configuração resultante dessa transformação, devese identificar e verificar, através de sua continuação, se houve transferência de função e assim identificar as possiveis direções das vozes. Os Acordes Vagantes costumam alterar o direcionamento da voz.

No Ex.48, o acorde G7/B é utilizado como Acorde Vagante para conectar as Regiões da Np e sm como Db7(b5). A nota Ré foi trocada de oitava e assume a posição do baixo já transformada em Réb. Esse movimento, Ré Réb, suaviza a passagem entre essas Regiões remotas, pois anuncia a Região da sm. No c.15, a Permutabilidade Maior/Menor é aproveitada para desenhar uma linha melódica em forma de resolução indireta ou cambiata. 0 acorde Bm7 sofre transformação da quinta, mas mantém sua fundamental baseada no II grau. Desta forma é criada uma linha cromática descendente com o Fá\#, que é transformado em Fá natural e dirige-se para a nota $\mathrm{Mi}$, quinta do acorde $\mathrm{A} 7 \mathrm{M}$. A continuação da linha é feita na direção contrária através da sensível (Sol\#) da região analisada $D$. A sensível conduz à sétima maior do acorde Napolitano, seguida pelo Sib, terça menor do acorde cifrado $\mathrm{Gm7}$, que é analisado como prolongamento do acorde Napolitano.

\section{2 - Substituição cromática e quase- diatônica em 14 de Novembro de 1996}

No Ex.49, o acorde cifrado como B7(\#9,b13) foi analisado como acorde vagante e considerado como Prolongamento do IV grau, correspondendo ao acorde F7 $(9, \# 11,13)$. Porém, pelo fato de ele surgir com a cifragem de seu correspondente B7, através do modelo cadencial II $\varnothing-V 7$, isto sugere que a nota substituta Ré\# (terça maior de B7) tenha surgido quase-diatônicamente (função centrífuga), produzindo a função específica de sensivel ascendente com potencial de resolução na nota Mi. Com a caracterização do Acorde Vagante, a nota Ré\# é enarmonizada como Mib (sétima menor de F7), sugerindo que a mesma tenha surgido como substituta cromática (função centripeta), com movimento em direção à nota Ré do próximo acorde.

No Ex.50, os acordes de sétima da Dominante, na sequência dos c. 5-6 podem ser realizados como estruturas de acordes vagantes. Neste caso, procurouse criar duas linhas de contraponto à melodia de modo que, no encontro dessas linhas fosse gerado uma estrutura Vagante. Sobre os dois primeiros acordes, Dm7 e G7, interpretamos o G7 como uma estrutura Vagante semelhante àquela do modo Lídio b7. Desta forma, a voz melódica deveria delinear o modo Sol Lídio b7. Por outro lado, esse mesmo modo é encontrado sobre o IV grau de Ré menor melódica, e essa compreensão possibilita utilizar o procedimento de Neutralização para promover o surgimento da décima primeira aumentada (\#11) no acorde G7. Após essa nota ser introduzida de maneira quase-diatônica, sua continuação para o próximo acorde Cm7 se dá por via cromática, de modo que a nota Dó\# ,

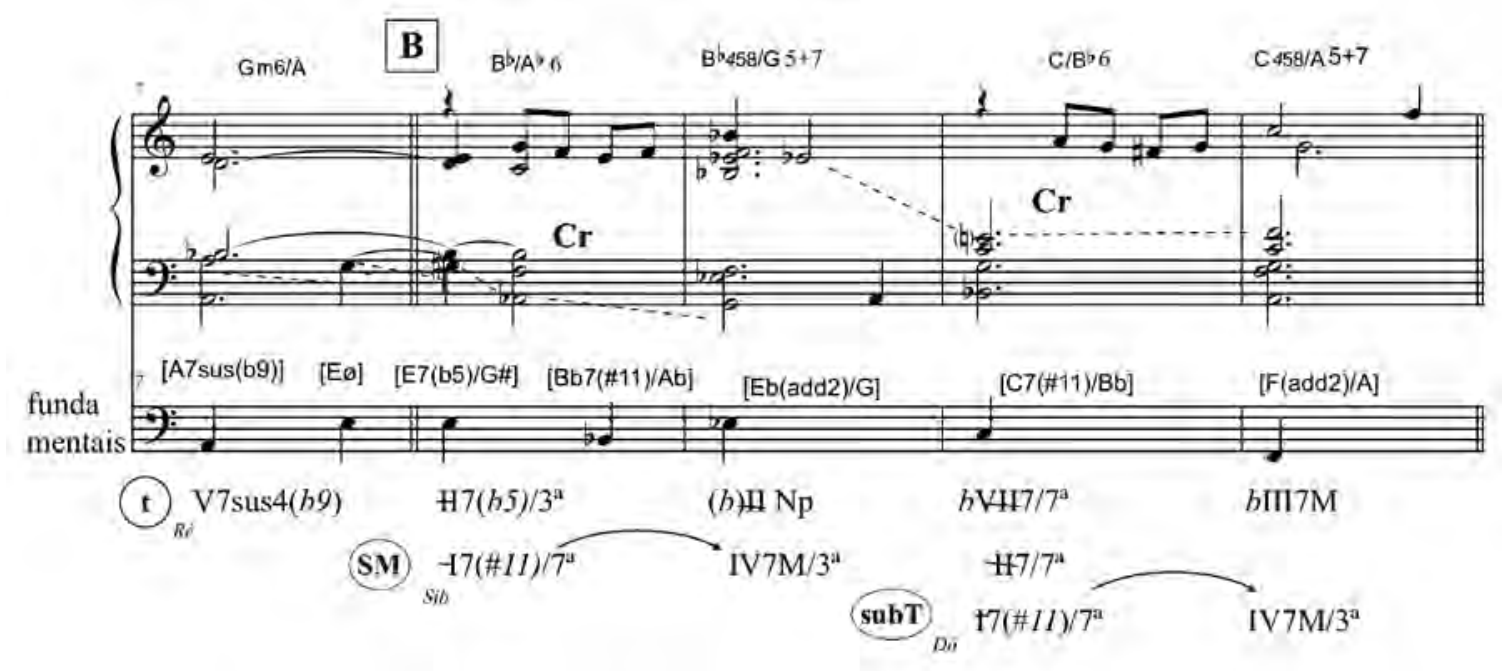

Ex.47 - Utilização dos direcionamentos das vozes transformadas em 9 de Agosto de 1996 de Hermeto Pascoal. 


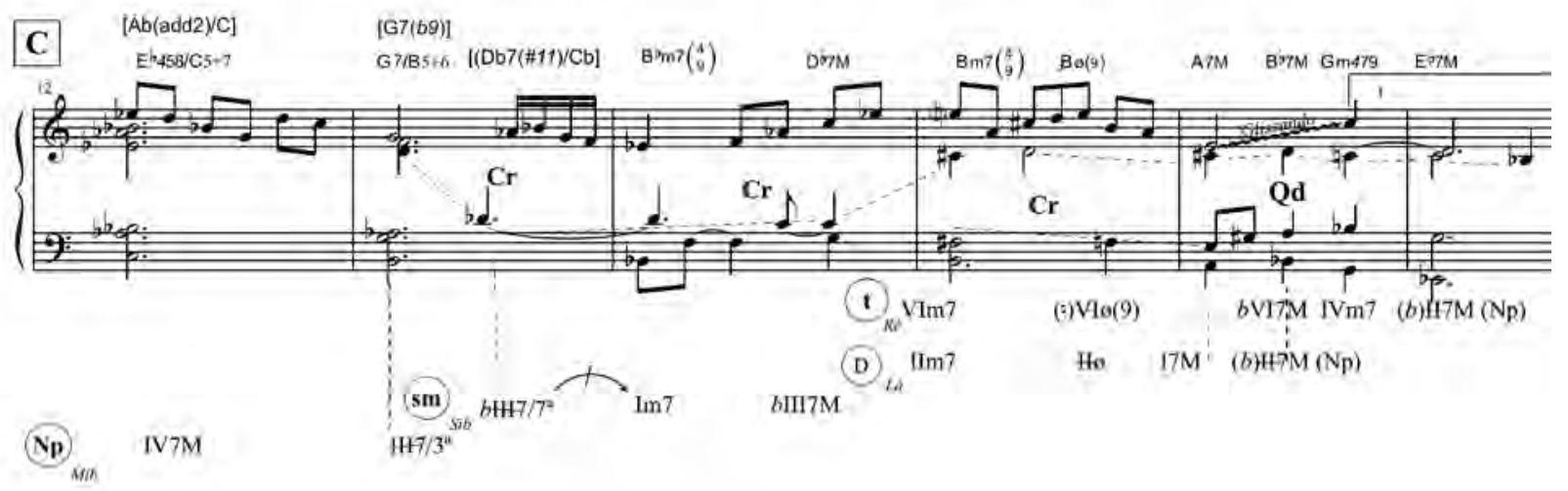

Ex.48 - Transformação preparando nova Região e Cromatismo gerado por Permutabilidade Maior/Menor em 9 de Agosto de 1996 de Hermeto Pascoal.

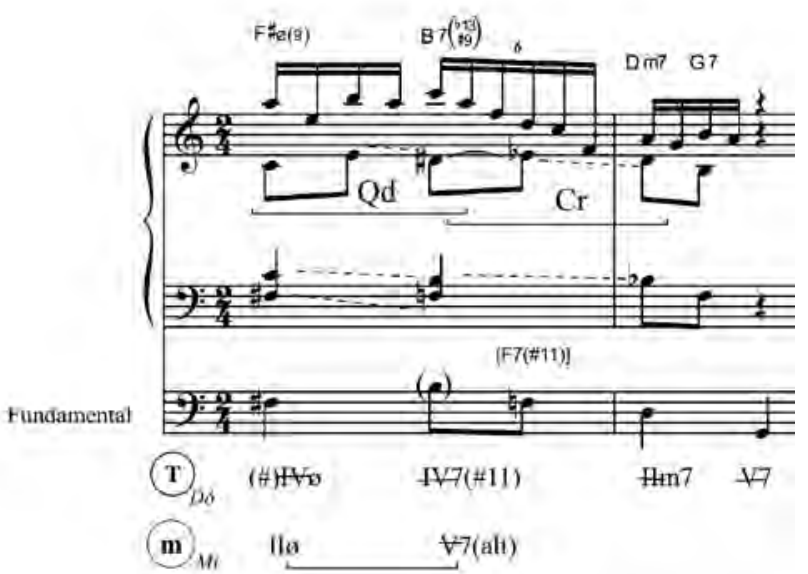

Ex.49 - Substituição cromática e quase-diatônica em um excerto de 14 de Novembro de 1996 de Hermeto Pascoal.

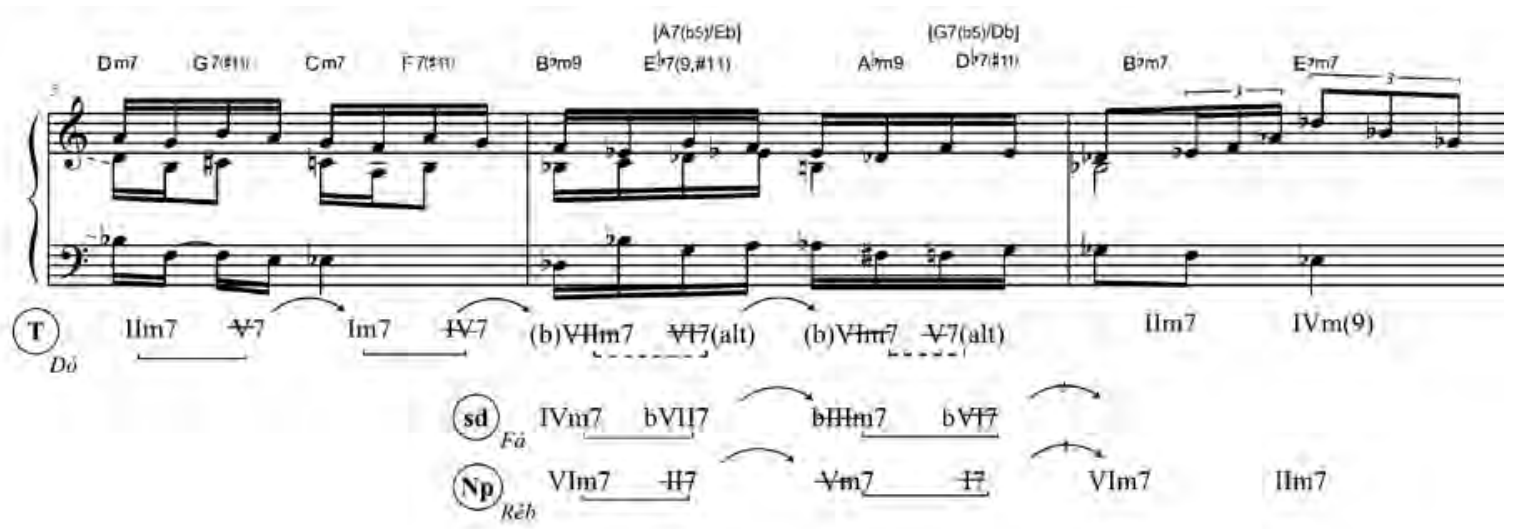

Ex.50 - Acordes vagantes na sequência dos c. 5-6 em 14 de Novembro de 1996 de Hermeto Pascoal. 
décima primeira aumentada, muda seu direcionamento, movendo-se em direção a nota Dó. Esse motivo melódico é utilizado em sequência sobre os próximos modelos IIV7. Entretanto, na terceira e quarta sequências, este é executado pela terceira voz.

0 Ex.51 ilustra um trecho da música que sofre uma sequência de modulações muito breves, no espaço de apenas um compasso, sempre realizadas por uma cadência Napolitana (modelo bH7M - I). No c.8, o acorde Fm7 funciona como $A b 7 \mathrm{M}$, dando início à sequência de cadências Napolitanas. Assim, este acorde é analisado como (b)H7M na Região da D (Sol maior). Logo depois da cadência, o I grau da D (Sol maior), é reinterpretado como IV da S/T (Ré maior). Essa Transferência de Função (ver tópico 3 acima)de I para IV, logo depois que a cadência Napolitana sofre repetições até 0 c.11, promove as modulações para T (Dó maior) - D (Sol maior) - S/T (Ré maior) - SM (Lá maior) - DM (Si maior).

No trecho compreendido nos c.8-11 foi analisado como progredindo da T para SM, através das Regiões Intermediárias [D], [S/T]. A Região da DM (Si maior) determina o clímax desse percurso, como uma espécie de movimento de bordadura, pois logo depois retorna para a SM (Lá maior). A partir deste ponto, a Região da SM (Lá maior) flutua para a M (Mi maior), e retorna para a T (Dó maior), através da Np (Réb maior). Mais uma vez, todas as modulações são feitas através da cadência Napolitana (Ex.51 e 52).

\section{6 - Considerações finais}

Ao rever a literatura sobre o ensino da harmonia tonal na música popular, observamos que, até a década de 1990, quase não havia materiais didáticos no Brasil (CHEDIAK, 1986, FARIA, 1991), situação que começou a mudar somente no século XXI com a publicação de trabalhos mais bem fundamentados (TINÉ, 2002; ALMADA, 2006; FREITAS, 2010). Da mesma forma, somente a partir da década de 1990 é que os trabalhos teóricos de Arnold SCHOENBERG $(1993,1999,2001,2004)$ ou sobre sua obra didática (DUDEQUE, 1997, 2004a, 2004b, 2005) começam a ser publicados no Brasil. Mas ainda são escassas as iniciativas no ensino da harmonia tonal, com seus procedimentos de afastamento da tonalidade em uma linguagem que busque a integração entre as linguagens das músicas popular e erudita. No presente artigo, buscamos rever, adaptar, propor sua utilização e aplicar na

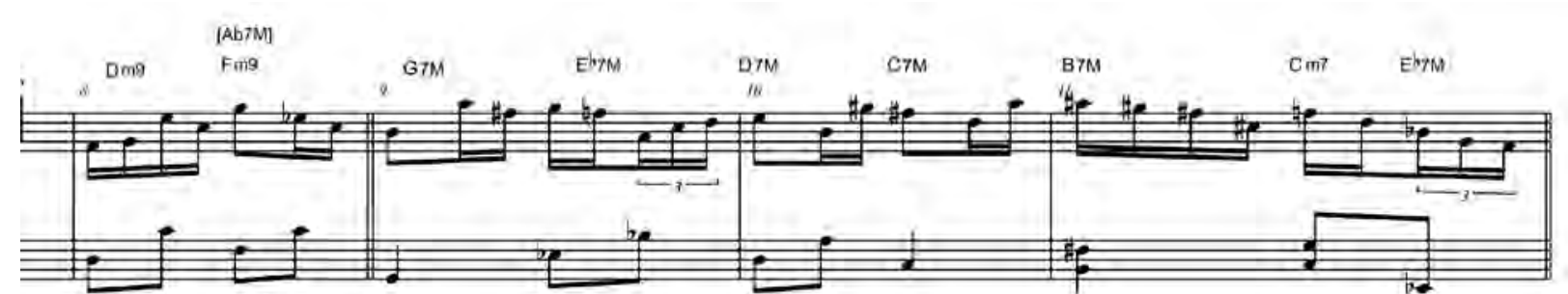

(T) $\lim 7 \quad \mathrm{FV} m(9)$

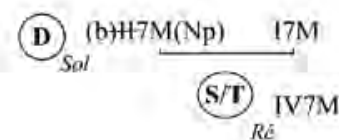

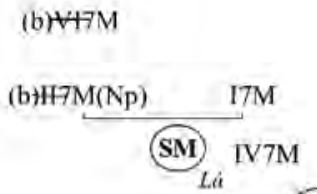

\section{(b) \\ (b) $\vee 7 \mathrm{M}(\mathrm{Np})$}

(DM) $(\mathrm{b}) H 7 \mathrm{M}(\mathrm{Np}) \quad 17 \mathrm{M}$

Ex.51 - Tonalidade Expandida com uso de cadências napolitanas nos c.8-11 em 14 de Novembro de 1996 de Hermeto Pascoal.

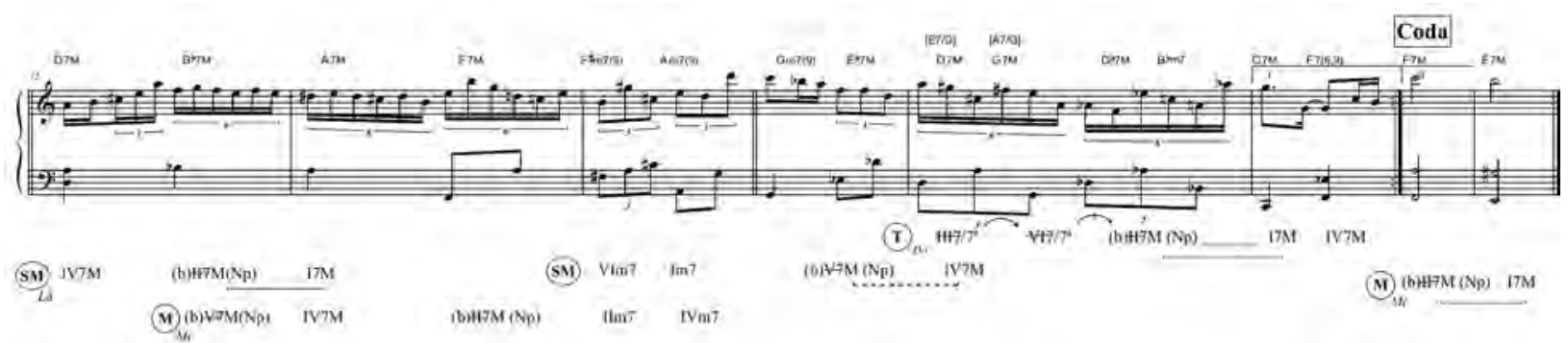

Ex.52 - Tonalidade Expandida com uso de cadência Napolitana nos c.12-17 em 14 de Novembro de 1996 de Hermeto Pascoal. 
música popular (aqui em duas canções instrumentais de Hermeto Pascoal), os diversos Conceitos Tonais, Funções Tonais e Contextos Tonais (e seus princípios) contidos no pensamento harmônico tonal de Schoenberg.

Consideramos que as contradições extremas entre 0 cromatismo e o diatonicismo expostas por Schoenberg, que eventualmente levam a questões como a omissão da tônica ou a existência de duas tônicas simultâneas, representam um ponto fundamental de conexão com a música popular. Trata-se de uma perspectiva que nos permite compreender e facilitar procedimentos de performance, composição e arranjo na música popular - especialmente no seu aspectos instrumental e improvisatório - que se consolidaram no meio não letrado, mas sim a partir da experiência prática - não teórica -, vivida nos palcos e construída com base na tradição aural e oral. Como Schoenberg no seu conceito de Monotonalidade, o músico popular consegue conviver bem e explicar grandes divagações harmônicas sem recorrer à modulação.

Finalmente, esperamos que o presente artigo (assim como o seguinte, publicado às p.70-95 desse número de PerMusi) possa contribuir para que os músicos - popular e erudito - possam melhorar suas ferramentas para compreender, arranjar, compor e improvisar musicalmente. Se o músico erudito, recorrendo à visão schoenberguiana de harmonia tonal, pode explicar melhor os trechos tonais harmonicamente mais obnubilados e perceber estruturas formais mais amplas sem recorrer à modulação, o músico popular pode, por outro lado, ampliar seu vocabulário de acordes e suas progressões e - o que ainda é raro - incluir, com mais liberdade e consciência - tanto ao nivel da improvisação, do arranjo ou da composição - o pensamento contrapontístico.

\section{Referências:}

ARAÚJO, Fabiano; BORÉM, Fausto. Variação Progressiva de Schoenberg em Hermeto Pascoal: análise e realização de duas lead sheets do Calendário do som. Per Musi. v.28. Belo Horizonte: UFMG, 2013. p.70-95.

BAKER, David. Jazz improvisation. Chicago: Maher, 1969.

BORÉM, Fausto; ARAÚJO, Fabiano. Hermeto Pascoal: experiência de vida e a formação de sua linguagem harmônica. Per Musi, n.22. Belo Horizonte: UFMG, 2010. p.22-43.

BUETTNER, Arno Roberto von. Expansão Harmônica: uma questão de timbre. São Paulo: Irmãos Vitale, 2004.

CHEDIAK, Almir. Dicionário de Acordes Cifrados. 2 ed. São Paulo: Irmãos Vitale S/A, 1984. Harmonia e Improvisação vol. I. Rio de Janeiro: Lumiar, 1986.

CUGNY, Laurent, Analyser le jazz. Paris: Outre Mesure, 2009.

DOBBINS, Bill. The contemporary jazz pianist. New York: Charles Colin, 1984.

DUDEQUE, Norton, E. Music Theory and Analysis in the Writings of Arnold Schoenberg (1874-1951). England: Ashgate, 2005. Schoenberg e a Função Tonal, Revista Eletrônica de Musicologia. Dep. Artes da UFPr Vol. 2.1.1997.

Sobre Harmonia de Arnold Schoenberg. Tradução de Marden Maluf, São Paulo: Editora da UNESP, 1999. Per

Musi: Revista Acadêmica de Música, Belo Horizonte, v.9, p.114-123, semestral 2004a.

Sobre os Apêndices dos Exercícios Preliminares em Contraponto de Arnold Schoenberg. Tradução

de Eduardo Seincman, São Paulo: Via Lettera, 2001 Per Musi: Revista Acadêmica de Música, Belo Horizonte, v.9, p.124-129, semestral 2004b.

FARIA, Nelson. A arte da Improvisação. Rio de Janeiro: Lumiar,1991.

FREITAS, Sérgio Paulo Ribeiro de. Teoria da harmonia na música popular: uma definição das relações de combinações entre os acordes na harmonia tonal. 1995.174 f. Dissertação (Mestrado em Música), Instituto de Artes, Universidade Estadual Paulista, São Paulo, 1995.

. Que acorde ponho aqui? Harmonia, práticas teóricas e o estudo de planos tonais em música popular. 2010. 817

f. Tese (doutorado), Instituto de Artes Universidade Estadual de Campinas. Campinas, SP, 2010.

GUEST, Ian. Arranjo. Rio de Janeiro: Lumiar, 1996. 
LEIBOWITZ, René. Schoenberg. São Paulo: Editora Perspectiva, 1981.

LEVINE, Marc, The jazz piano book. Berkeley: Sher Music,C0., 1989.

MEHEGAN, John F. Jazz improvisation Vol.1-Tonal and rhythmic principles. New York: Watson-Guppil (1978) $\left[1959,1^{\text {a }}\right.$ edição].

MILLER, Ron, Modal Jazz:Composition and Harmony Vol.1, Germany: Advance Music, 1996. Modal Jazz:Composition and Harmony Vol.2, Germany: Advance Music, 1997.

PASCOAL, Hermeto. 9 de agosto de 1996. In: Calendário do som. São Paulo: Editora Senac, 2000a. p.70. (Partitura musical em forma de lead sheet).

14 de novembro de 1996. In: Calendário do som. São Paulo: Editora Senac, 2000b. p.167. (Partitura musical em forma de lead sheet).

substituir por:

9 de junho de 1997. In: Calendário do som. São Paulo: Editora Senac, 2000c. p.374. (Partitura musical em forma de lead sheet).

9 de junho de 1997 (Calendário do som): manuscrito e lead sheet de realização. Realização e edição de Fabiano Araújo. Per Musi.n.28. Belo Horizonte: UFMG, 2013. p.99-101.

23 de junho de 1996. In: Calendário do som. São Paulo: Editora Senac, 2000d. p.23. (Partitura musical em forma de lead sheet).

23 de junho de 1996 (Calendário do som): manuscrito e lead sheet de realização. Realização e edição de Fabiano Araújo. Per Musi.n.28. Belo Horizonte: UFMG, 2013. p.96-98.

REILLY, Jack. The Harmony of Bill Evans. New York: Unichrom Ltd. 1993.

RUSSEL, George. Lydian Chromatic Concept of Tonal Organization Vol.1 - The Art and Science of Tonal Gravitaty. Brookline: Concept Publ. Co. 2001 [1953, 1ª edição].

SALZER, Felix. Structural Hearing, Tonal Coherence in Music. New York: Dover Publications. 1982 [1952, 1a edição].

SCHOENBERG, Arnold. Harmonia. Trad. Marden Maluf. São Paulo: Editora UNESP, 1999 [1911].

Structural Functions of Harmony. Ed. Leonard Stein. New York: W. W. Norton \& Company, 1969 [1954].

Funções Estrururais da Harmonia. Trad. Eduardo Seincman, Ed. Leonard Stein. São Paulo: Via Lettera, 2004 [1969].

Exercícios Preliminares em Contraponto. Trad. Eduardo Seincman, Ed. Leonard Stein. São Paulo:

Via Lettera, 2001 [1963].

Fundamentos da Composição Musical. Trad. Eduardo Seincman, 2 ed. São Paulo: Editora da Universidade de São Paulo, 1993 [1967].

Models for beginners in composition: syllabus and glossary. New York: G. Schirmer, 1943.

The Musical Idea and the logic, Technique and art of its presentation. Publicado anteriormente em 1995. Ed. de Patricia Carpenter e Severine Neff. Bloomington: Indiana University Press, 2006.

TINÉ, Paulo José de S. A Harmonia no Contexto da Música Popular - Um Paralelo com a Harmonia Tradicional. Revista Internacional VIDETUR-LETRAS 6. Editora Mandruvá, 2002. Disponível na Internet $:<$ www.hottopos.com/vdletras6/TINÉ.htm>.

ZAG0, Luis Gustavo. Composição e improvisação no Calendário do Som. em Repom no 4, Julho de 2007. Disponivel na internet: http://www.repom.ufsc.br/repom4/ (acessado em 15/05/2010)

\section{Notas}

1 A tradução deste conceito, do alemão para o português, feita por Marden Maluf para na edição brasileira de Harmonia, é Acorde Errante. Optamos pela tradução de Eduardo Seincman, (do inglês para o português) de Funções Estruturais da Harmonia, Acordes Vagantes (em inglês Vagrant Chords).

2 A respeito desta concepção de Condução de Vozes, FREITAS (1995, nota de rodapé, p.4) a define como: "0 domínio da harmonia que trata das técnicas de encadeamento dos acordes no que tange os movimentos melódicos (lineares) que as notas constitutivas desses acordes executam quando se combinam"

3 De outra forma poderiamos entender o acorde F\# como o IV grau de Dó maior com a fundamental alterada, possibilidade que é rejeitada por Schoenberg.

4 Derivação sugerida pelo teórico vienense Simon Sechter.

5 Essa conclusão de DUDEQUE (2005, p.112) corrobora a afirmação de SALZER (1982, p.26) sobre os movimentos estruturais. Progressões baseadas na Progressão de Fundamentais I - V - I não são as únicas estruturas sobre as quais os movimentos encontram expressão. Isso se aplica especialmente à música de hoje que tende a evitar a obviedade inerente à relação harmônica tônica - dominante.

6 Essa observação corrobora o pensamento schoenberguiano de que a Tônica está o tempo todo sobre a influência de seus satélites, a D e a SD. As condições de equilibrio tonal dependem da tensão entre essas duas forças sobre a Tônica. Com a interpretação de DUDEQUE (2005, p.102) sobre a 
disposição do Quadro de Regiões, onde afirma: "No lado direito estão as Regiões relacionadas e/ou derivadas da Região Subdominante, enquanto no lado esquerdo, estão as Regiões derivadas da Região da Dominante", podemos acrescentar que as condições de equilibrio tonal dependem da tensão entre as forças da SD - e suas Regiões derivadas ou relacionadas - e da D - e suas Regiões derivadas ou relacionadas - conforme disposição do Quadro de Regiões.

7 Esse pensamento de prolongamento tonal surge da ideia de Sucessão e Progressão Harmônica. Apesar de ser obviamente schenkeriano, o conceito de prolongamento em SALZER (1962), aproxima-se de algumas ideias de Schoenberg. Para SALZER (1982, p.16), o termo Prolongamento, pode ser aplicado à expansão de uma Progressão de um acorde para outro, ou à expansão de um único acorde.

8 Nesse exemplo extraído de Funções Estruturais da Harmonia, SCHOENBERG (2004) não utiliza a alteração da fundamental em parênteses (b), ou (\#), conforme adotamos nesse trabalho.

9 DUDEQUE (2005, p.93, nota de rodapé) alerta que a compreensão do termo "prolongamento da fundamental" deve ser compreendido como "extensão da função específica da fundamental de um acorde", e que não deveria ser associado ao significado schenkeriano do termo "prolongamento".

10 Escala de Acorde é a escala formada pelo conjunto das notas que caracterizam o acorde, chamadas Notas de Acorde, e as notas que o enriquecem, chamadas Notas de Tensão.

11 CHEDIAK (1986, p.337), define Escala de Acorde como "o conjunto das notas disponíveis que uma cifra apresenta para formar harmonia ou linha de improviso".

12 Sons enarmônicos são sons iguais que recebem nomes diferentes.

13 A imitação do modelo cadencial IVm - V levaria à produção dos mesmos acordes, devido à caracteristica simétrica dessas relações.

14 Os passos superfortes de $2^{\text {a }}$ ascendente e descendente são considerados abreviações de dois passos crescentes (SCHOENBERG, 1999, p.181-185).

Fabiano Araújo, pianista e compositor, desenvolve tese de doutorado sobre o jazz contemporâneo, desde 2012, na Universidade Paris-Sorbonne (Paris-IV), com bolsa CAPES, junto ao grupo JCMP-OMF (Jazz, chanson et musiques populaires - Observatoire Musical Français). É Mestre em Música pela Escola de Música da UFMG e Bacharel em Música Popular pelo Centro de Artes da UNICAMP. É Professor Assistente do Centro de Artes da Universidade Federal do Espírito Santo (UFES), onde contribuiu para a criação o curso de Bacharelado em Música, habilitação em Composição com ênfase em Trilha Musical. Possui 4 CD's lançados: O Aleph (2007); Calendário do Som - 9 dias (2009) de Hermeto Pascoal, gravado e publicado em Portugal, com a participação do contrabaixista norueguês Arild Andersen do baterista Alexandre Frazão (Brasil/Portugal) e do saxofonista Guto Lucena (Brasil/Portugal); Rheomusi (2011) em trio com Arild Andersen e Naná Vasconcelos, e Baobab trio (2012), com peças de Radamés Gnattali, Baden Powell além de música improvisada em trio.

Fausto Borém é Professor Titular da UFMG, onde criou o Mestrado e a Revista Per Musi. Pesquisador do CNPq desde 1994, publicou dois livros, três capítulos de livro, dezenas de artigos sobre práticas de performance e suas interfaces (composição, análise, musicologia, etnomusicologia da música popular e educação musical) em periódicos nacionais e internacionais, dezenas de edições de partituras e recitais nos principais eventos nacionais e internacionais de contrabaixo. Recebeu diversos prêmios no Brasil e no exterior como solista, teórico, compositor e professor. Acompanhou músicos eruditos como Yo-Yo Ma, Midori, Menahen Pressler, Yoel Levi, Arnaldo Cohen, Luis Otávio Santos e músicos populares como Hermeto Pascoal, Egberto Gismonti, Henry Mancini, Bill Mays, Kristin Korb, Grupo UAKTI, Toninho Horta, Juarez Moreira, Tavinho Moura, Roberto Corrêa e Túlio Mourão. Participou do CD e DVD 0 Aleph de Fabiano Araújo Costa. 